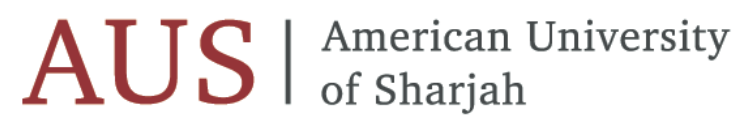

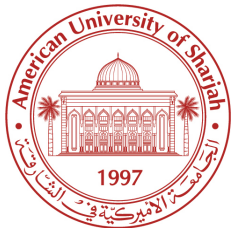

SCHOOL OF BUSINESS AND MANAGEMENT WORKING PAPER SERIES

SBMWPS: $15-12 / 2013$

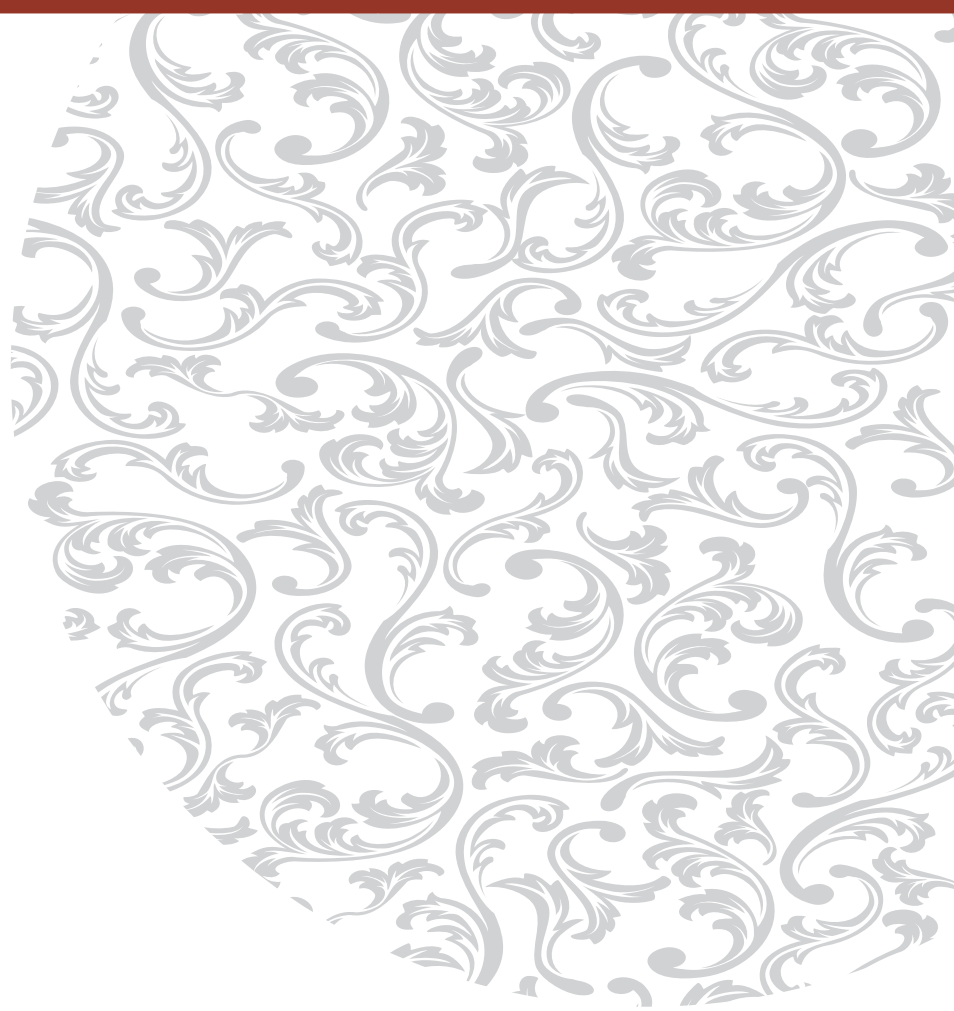

The Effects of Analyst Forecast Properties on the Cost of Debt: International Evidence

Narjess Boubakri

Sadok El Ghoul Omrane Guedhami Anis Samet 


\title{
The Effects of Analyst Forecast Properties on the Cost of Debt: International Evidence
}

\author{
Narjess Boubakri \\ American University of Sharjah \\ Sadok EI Ghoul \\ University of Alberta \\ Omrane Guedhami \\ University of South Carolina
}

\section{Anis Samet}

American University of Sharjah

The views expressed in papers published in our series are those of the author(s) and do not necessarily represent those of any department at SBM, the SBM itself, the American University of Sharjah (AUS) and/or any of their affiliates. Additionally, all papers in the series are made available on an "as is" basis without warranties of any kind. We, that is, the relevant department at SBM, SBM, AUS and/or any of the affiliates, hereby expressly disclaim any warranties of any kind, whether expressed or implied, including without limitation, the warranties of noninfringement, merchantability, and fitness for a particular purpose. Furthermore, we offer no warranties, expressed or implied, regarding the accuracy, sufficiency or suitability of the material found in the published papers. The users have the sole responsibility for inspecting and testing all content to their satisfaction before using them. 


\title{
The Effects of Analyst Forecast Properties on the Cost of Debt: International Evidence*
}

\author{
Narjess Boubakri \\ American University of Sharjah, UAE \\ nboubakri@aus.edu \\ Omrane Guedhami \\ University of South Carolina, Columbia, SC, USA \\ omrane.guedhami@moore.sc.edu
}

University of Alberta, Edmonton, AB, Canada elghoul@ualberta.ca

Anis Samet 


\begin{abstract}
This study investigates whether financial analysts play a governance role in international debt markets by examining the link between analyst forecast characteristics and the cost of debt financing. Using a sample of 2,686 bond issues from 35 non-U.S. countries, we find statistically and economically significant evidence that analyst activities lower bond yield spreads, after controlling for bond- and firm-level control variables as well as various country-level institutional factors. We also find that this relation holds in countries with weak and strong governance institutions, although the effects appear to be economically more important in the former. Overall, our non-U.S. findings extend the U.S. evidence in Mansi et al. (2011) that financial analysts play an important governance role as information intermediaries between firms and market participants.
\end{abstract}

\title{
December 2013
}

JEL classification: G34; G32

Key words: Analyst Forecasts; Disclosure; Creditor Rights; Cost of Debt

* We thank Najah Attig, Ruiyuan Chen and Walid Saffar for constructive comments. We appreciate generous financial support from Canada’s Social Sciences and Humanities Research Council. 


\section{Introduction}

The cost of debt issue has been the subject of considerable attention in the literature, particularly the cost of debt in U.S. markets, where corporations have issued a total of $\$ 4.6$ trillion in corporate bonds, compared to $\$ 1.5$ trillion in equity over the 1997 to 2008 period alone (Bessembinder and Maxwell, 2008). Among scholars, there is consensus that the cost of debt is primarily related to firm-level characteristics such as firm size, leverage, the volatility of assets, and corporate disclosure (Sengupta, 1998; Yu, 2005), corporate governance (Anderson et al., 2003; Mansi et al., 2004; Pittman and Fortin, 2004; Ashbaugh-Skaife et al., 2006), and earnings quality (Francis et al., 2005, 2008). Recent evidence further shows that earnings news channels information to credit markets (Callen et al., 2009; Easton et al., 2009; DeFond and Zhang, 2013), and that analyst forecast properties affect the cost of debt and credit ratings (Güntay and Hackbarth, 2010; Mansi et al., 2011). Yet, little is known about the determinants of corporate debt pricing outside the U.S. ${ }^{1}$ Extending this line of research, in this paper we offer the first evidence on the subject by looking at the role of analysts in international debt markets.

As Lang et al. (2004, p. 592) suggest, by providing "potentially important scrutiny over management's actions,” financial analysts play a dual role that essentially consists of (1) reducing agency problems arising from opportunistic managers' behavior, and (2) reducing information asymmetry problems between managers and outside investors through information gathering and reporting activities. In this paper, we examine the link between analyst forecast properties (i.e., forecast dispersion, forecast accuracy, forecast revision, and their principal component score) and both credit ratings and credit spreads in a large sample of bond issues from a diversified sample of

\footnotetext{
${ }^{1}$ According to Gozzi et al. (2012), bond markets constitute a larger and more internationalized source of capital for firms than equity markets. Analyzing data for nearly 14,000 firms from 99 countries over the 1991 to 2008 period, they show that the aggregate amount raised by firms in bond markets around the world almost doubled in that period.
} 
35 countries. Specifically, we ask the question: Do analysts affect credit ratings and credit spreads of international firms? In other words, does the added scrutiny of financial analysts play an informational role around the world once we account for other country-specific external monitoring mechanisms?

Following arguments in Lang and Lundhom (1996), who show that firms with more informative disclosure policies have larger analyst following, more accurate analyst earnings forecasts, less dispersion among individual analyst forecasts, and less volatility in forecast revisions, we assess analyst activity using the above-mentioned forecast properties. By examining the link between these properties and both credit ratings and credit spreads, we extend recent evidence from the U.S. in Mansi et al. (2011), who show that analyst activity reduces bond yield spreads and conclude that "the information contained in analyst forecasts is valued outside the equity market and provide[s] an additional channel in which better information is associated with a lower cost of capital” (p. 116). According to the authors, their results are consistent with analyst activity improving the information environment of the firm.

Extending the evidence in Mansi et al. (2011) from the U.S. to an international context is important for at least two reasons. First, outside the U.S., institutional differences in legal and financial systems could condition the availability of information and hence the role that financial analysts play as financial intermediaries and information providers. Prior evidence shows that the extent of information asymmetry, which is at the root of the wedge between the internal and external costs of funding, depends on the institutional context (e.g., Love, 2003; Khurana et al., 2006; Islam and Mozumdar, 2007). Compared to other countries, the U.S. has a well-developed "frictionless" financial market with strong investor protection and contract enforcement, and with relatively better access to outside financing (Francis et al., 2005). Consequently, the results documented for the U.S. may not generalize to other countries with different legal and institutional environments. A sample with a wide variety of institutions and legal environments provides a natural laboratory in which to explore whether analysts play as significant a role in debt markets around the world as in the U.S.

Second, in this paper, the institutional environment involves country-specific legal institutions. A well-functioning legal system is considered the most effective mechanism in limiting 
insiders' incentives and ability to expropriate shareholders (Shleifer and Vishny, 1997), and in reducing their informational advantage (Brockman and Chung, 2003). Two separate strands of literature in accounting and finance link the legal system (and investor protection) to analysts' behavior and the corporate cost of debt financing. One line of research shows that analyst forecast characteristics vary across countries. As Chang et al. (2001) observe, there is substantial variation in the extent and accuracy of analysts' forecasts in their sample of 47 countries. The authors find that a large percentage of this variation is explained by country-specific institutions. Related studies also show that disclosure quality and transparency, seen as a primary determinant of analyst forecast accuracy, are a function of the institutional infrastructure of the country (Bushman et al., 2004; Lang et al., 2004). Earnings quality is also found to be lower in environments where investor protection is weak. Compelling evidence on the price informativeness of earnings is reported in Morck et al. (2000), who find that firm-specific information is less important in countries with weak property rights. This evidence is supported by Chan and Hameed (2006), who document that the information that financial analysts in emerging markets collect has more country-specific than firm-specific content. The other line of research shows that the cost of debt financing also depends on countrylevel institutions. In their seminal paper, Djankov et al. (2007) show that well-protected debt claimants normally require lower interest rates. Similarly, Boubakri and Ghouma (2010) show that bond spreads are negatively related to investor protection, while bond ratings increase with the level of investor protection in the country. 2 These results suggest that the effects of analyst forecast properties on the cost of debt and ratings are likely to vary across countries.

The above arguments motivate our focus on the link between analyst forecasts and credit spreads/ratings in an international sample that is diversified across firms and countries. To the extent that debt contracts are based on accounting information about borrowers (Li, 2010), we follow Mansi et al. (2011) and posit that financial analysts can provide information that reduces information asymmetry between borrowers and lenders, thus helping the latter assess firm default risk. In addition, the information provided by analysts can serve as a monitoring mechanism over managers and reduce the extraction of private benefits, and in turn a firm's default risk. These two channels (information and monitoring) should therefore result in a higher credit rating and a lower cost of

\footnotetext{
${ }^{2}$ Using a sample of 260 Yankee bonds issued by non-U.S. firms, Miller and Puthenpurackal (2002: p. 455) find evidence that investors charge higher bond costs to firms located in countries with poor protection of investors' rights and to firms that "do not have a prior history of ongoing disclosure."
} 
debt. It is unclear, however, how this expectation will stand in diverse institutional settings. Indeed, the empirical magnitude of these effects in a multi-country setting is an open question, which we seek to address in this paper.

Using a sample of 2,686 bonds issued by 394 firms from 35 non-U.S. countries between 1991 and 2007, and following the approach in Mansi et al. (2011), we find statistically and economically significant evidence that analyst forecast characteristics-dispersion, accuracy, revision, as well as a principal component including all these characteristics-affect firms' cost of debt financing and credit ratings. This pattern persists when we control for an extensive set of bondspecific and other firm-specific characteristics, when we employ alternative samples, and when we include additional country-level factors. In additional analyses, we find that the statistically significant relation between analyst forecast characteristics and firms' debt financing costs holds in countries with weak and strong governance institutions, although these relations appear to be economically more important in countries with weak institutions. Overall, our findings suggest that analyst activity matters to debt pricing in an international setting.

Our study contributes to the literature in several ways. First, we answer the call by Ramnath et al. (2008: p. 68) for "more international research describing institutional and regulatory factors that create cross-country differences in the role of analysts and the properties of their forecasts." Second, considering the combined role of various institutional environments enhances our understanding of the role of financial analysts in international capital markets, and particularly in debt markets from institutionally different environments. In environments where information disclosure and other corporate governance mechanisms are weak, assessing the role of analysts could result in important policy implications as it advances our understanding of the potential substitutability/complementarity between firm- and country-level monitoring mechanisms. Third, by focusing on the link between analyst forecast properties and the cost of debt in firms' home countries, we complement recent evidence that focuses on this issue for a sample of bonds issued by U.S. firms (Güntay and Hackbarth, 2010; Mansi et al., 2011). Fourth, according to Chang et al. (2001), the financial crises in Asia and other emerging markets highlight the importance of information intermediaries such as analysts to the functioning of capital markets. Considering crosscountry differences furthers our understanding of how capital markets function around the world, and of how bondholders assess the default risk of firms. Ultimately, this study helps in the 
identification of factors that drive the cost of debt financing and hence firms' financing and growth potential, not only across firms but also across countries. This issue is important as it directly affects overall economic growth. The lack of evidence on this subject is puzzling since debt, as discussed above, constitutes an important external source of financing for publicly traded firms around the globe.

The rest of the paper is organized as follows. Section 2 reviews prior research and develops our testable hypotheses. Section 3 describes our sample and outlines the regression variables. Section 4 presents the empirical results. Section 5 reports robustness tests. Finally, Section 6 concludes.

\section{Hypothesis development}

\subsection{Analyst forecast properties and debt pricing}

In this paper, we explore the relations between credit ratings/spreads and properties of analysts' forecasts. The analyst forecast variables most widely used in the literature are: (1) forecast accuracy, defined as the negative absolute value of the difference between the median forecast and actual earnings per share (EPS) deflated by the stock price, (2) forecast dispersion, defined as the standard deviation of the most recently revised forecasts by all analysts deflated by the stock price,3 (3) forecast revision, defined as the standard deviation of the difference between the median forecast and the lagged median forecast by all analysts deflated by the stock price, and (4) analyst forecast factor, an index using principal component analysis based on the three previous analyst forecast variables as those variables are highly correlated.

While the literature devotes much attention to the link between some or all of these properties and firm performance, or the cost of equity capital, scholars have only recently turned their attention to the potential spillover effects of these properties on debt pricing. Mansi et al. (2011) summarize prior research implying that an inverse relation should exist between analysts' activities and the cost of debt financing for two reasons: analyst forecasts reduce information asymmetry between firms and market participants, and analyst forecasts serve as a governance mechanism by increasing the monitoring of managerial behavior and market discipline.

\footnotetext{
${ }^{3}$ According to Collin-Dufresne et al. (2001), forecast dispersion largely captures future cash flow uncertainty in their sample of corporate bonds.
} 
In this paper, we also hypothesize that analyst activity can increase credit ratings and reduce the cost of debt financing. When lending money to corporations, individual investors and financial institutions are primarily concerned with the default risk of the firm, which is determined by its ability to meet the promised stream of interest and principal payments on its outstanding debt over the life of the bond. Therefore, to bondholders, information about the default risk of the firm is important, including financial analysts’ earnings predictability given that such information helps investors estimate the uncertainty about future earnings, future cash flows, and hence firm value. To the extent that better earnings predictability can be perceived as a higher probability of payment and hence lower risk, we expect the cost of debt financing to be related to analyst forecast characteristics. In a similar vein, Mansi et al. (2011, p. 119) provide the following theoretical rationale based on Duffie and Lando's (2001) model: as the value of expected future cash flows (i.e., firm value) is not perfectly observable, it is likely that "the true firm value is actually near its default boundary". This probability of default decreases as investors more effectively estimate the distribution of firm value, suggesting that information environments allow outside investors to more accurately assess true firm value. Therefore, "to the extent that analysts' activity impacts the information structure of the firm, their forecasts should matter to corporate bond yields” (Mansi et al., 2011, p. 119). 4

The role of financial analysts in monitoring managers and constraining the extraction of private benefits is another channel through which analyst activity can affect debt pricing. In stressing their monitoring role, Lang et al. (2004, p. 592) explain that "[i]n the process of deciding which firms to follow and providing earnings forecasts, price targets, and buy-sell recommendations, analysts gather information from a wide array of sources both internal and external to the firm to assess its economic viability and investment potential. As a consequence, they provide potentially important scrutiny over management's actions.” This improved monitoring should increase a firm’s expected cash flows and hence reduce its probability of default (Cheng and Subramanyam, 2008). Prior research provides empirical evidence supporting this governance role of analysts (e.g., Lang et al., 2004; Knyazeva, 2008). Given evidence that effective corporate governance is also valued by bondholders (e.g., Bhojraj and Sengupta, 2003; Klock et al., 2005), we also expect analyst activity to matter for bond pricing.

\footnotetext{
${ }^{4}$ In addition, prior research suggests that an improved information environment increases firms' ability to access capital (e.g., Khurana et al., 2006). Given that credit rating agencies incorporate access to financing in their debt ratings (as it reduces default risk), analysts' information production activities should impact ratings (Cheng and Subramanyam, 2008).
} 
Consistent with these conjectures on the informational and monitoring roles of financial analysts, Mansi et al. (2011) examine the relation between debt pricing and analyst forecast variables using bonds issued by U.S. firms and find that credit ratings and credit spreads are statistically significantly related to analyst forecast variables. When including each analyst variable separately, the authors find that higher dispersion in analysts' forecasts, more forecast revisions, and lower forecast accuracy are associated with lower credit ratings. ${ }^{5}$ Similarly, they find that the forecast dispersion and forecast revision variables are significantly positively related to credit spreads. Güntay and Hackbarth (2010) also find a positive and statistically significant relationship between credit spreads and analyst forecast dispersion using bonds issued by U.S. firms, consistent with the hypothesis that in corporate bond markets, forecast dispersion is a proxy for future cash flow uncertainty (Collin-Dufresne et al., 2001) rather than a measure of investors' divergence of opinion (Miller, 1977).

Turning to credit ratings, Cheng and Subramanyam (2008) analyze the link between analyst following and ratings, and posit that because of the monitoring and informational roles of financial analysts, analyst following should decrease default risk (as proxied by credit ratings). Looking at another property of analyst forecasts, namely, earnings forecast dispersion, and focusing on a sample of U.S. firms, Avramov et al. (2009) find that the negative cross-sectional relation between dispersion in analysts' earnings forecasts and future stock returns reflects financial distress captured by credit rating downgrades. Specifically, they show that the profitability of dispersion-based trading strategies is specific to the worst-rated stocks and obtains only during periods of financial distress. Importantly, suggesting a link between analyst characteristics and credit ratings, Avramov et al. (2009: p. 101) conclude that in these periods "prices of low-rated stocks decline substantially and the uncertainty about firm fundamentals (measured by analyst forecast dispersion, forecast revisions, or earnings surprises) rises considerably.”

Based on these arguments and prior literature, our two main hypotheses are as follows: ${ }^{6}$

\footnotetext{
${ }^{5}$ However, when Mansi et al. (2011) consider all three analyst forecast measures in the same regression, only the forecast dispersion and forecast revision variables remain statistically significant. Mansi et al. (2011) also find that the analyst factor is significantly positively related to bond ratings.

${ }^{6}$ It is possible that the effect of analyst forecast characteristics is captured by credit ratings rather than credit spreads given that the bond market is dominated by institutional investors and is served by its own information intermediaries, namely, credit rating agencies (Mansi et al., 2011). Our findings should therefore shed light on whether there is an
} 
$H_{1}$ : Credit ratings are positively related to forecast accuracy and negatively related to forecast dispersion and revisions. Credit ratings are positively related to the analyst forecast factor.

$\mathrm{H}_{2}$ : Credit spreads are negatively related to forecast accuracy and positively related to forecast dispersion and revision. Credit spreads are negatively related to the analyst forecast factor.

\subsection{Analyst forecast properties and debt pricing: The role of the institutional environment}

We next investigate whether the link between analyst forecast properties and credit ratings/spreads is conditional on the prevailing institutional environment. Existing literature provides insights on the importance of institutions to the functioning of capital markets and to securities pricing. One strand of the literature offers international evidence on the country-level determinants of credit ratings/spreads. For instance, La Porta et al. (1998) examine the extent to which debtholders (and more generally, creditors) are protected in 49 developed and emerging countries. They observe that common law countries offer stronger legal protection for debtholders compared to civil law countries. Adding to this evidence, Djankov et al. (2007) document a significant relation between the development of private credit and legal creditor rights. As a consequence, better-protected debt claimants are expected to require lower interest rates. Using a multinational sample of debt-issuing firms from developed and developing countries, Boubakri and Ghouma (2010) focus on the link between the institutional environment and credit spreads/ ratings. They show that the quality of investor and creditor protection does indeed condition spreads and ratings across institutionally diverse environments. Specifically, higher investor and debtholder protection reduces spreads and increases ratings. Another international study by Ellul et al. (2007) focuses on a sample of family firms that issued American Depositary Receipts (ADRs) in the U.S. and finds that these firms, which are from lower quality institutional environments, benefit from lower debt costs upon cross-listing.

Another strand of the literature focuses on the country-level determinants of transparency and analyst activity around the world. Chang et al. (2001) follow La Porta et al. (1998), who highlight that weakly protected minority shareholder rights worldwide are likely to affect the information made available to minority shareholders, and thus to analysts, and examine the accuracy of analysts' forecasts around the world. The authors find wide variation in the extent and accuracy of analyst forecasts in their sample of 47 countries, which they attribute to institutional factors such as 
countries' legal systems and information infrastructure. Building on this idea, Hope (2003) examines the effects of variation in firm-level disclosure in a cross-country setting on the accuracy of financial analysts' earnings forecasts. Hope (2003: p. 236) notes that "considerable variation persists in enforcement worldwide, even as cross-country differences in accounting measurement have diminished.” Using analyst following as a proxy for the information environment, the author shows that disclosures are less positively correlated with forecast accuracy when a firm's analyst following is high (i.e., in a better information environment). In addition, he finds that strong enforcement of accounting standards (which make reporting decisions more predictable) reduces uncertainty about firms' reporting choices, thus making forecasting easier. The impact of institutional and political variables on the level of transparency is further examined by Bushman et al. (2004), Lang et al. (2004), and Bushman and Piotroski (2006).

Based on this discussion, we posit that in countries where creditor rights are better protected and rules on disclosure and accounting information are better enforced, analyst forecast characteristics may be less correlated with credit ratings/spreads, because such environments have less information asymmetry and thus less need for analysts' services. This conjecture is consistent with Lang et al. (2004), who argue that the governance role of analysts is likely to be particularly valuable in international environments where governance mechanisms are weak. ${ }^{7}$ We state our third hypothesis as follows: ${ }^{8}$

$H_{3}$ : The impact of analyst forecast properties on the cost of debt is related to the institutional environment in place.

7 Consistent with this conjecture, Lang et al. (2004) find evidence suggesting that minority shareholders value the additional scrutiny associated with analyst activity (i.e., analyst following) in countries with weak investor protection. In this paper, in addition to analyst following we focus on the value of various analyst forecast characteristics in the international corporate bond markets.

8 An alternative view would suggest that the value of analysts in weak institutional environments may not be discernible because any benefit to outside investors is likely to be expropriated by insiders or even analysts, who, for example, tend to trade on information before its disclosure to the public (e.g., Claessens et al., 2002; Lang et al., 2004). In addition, analysts' ability and incentives to collect information is constrained in weak property rights environments because information is often costly to obtain (Claessens et al., 2002). 


\section{Data}

\subsection{Sample construction}

To test the effect of analyst forecast characteristics on credit ratings and credit spreads, we rely on various databases. First, we extract bonds issued all over the world from the Securities Data Company (SDC) Platinum Global New Issues Database. We consider bonds issued between 1991 and 2007. ${ }^{9}$ We exclude government bonds, sovereign agency issues, and bonds issued by financial firms. Further, due to the lack of information on the rate of reference for floating rate bonds, we limit attention to fixed rate bonds. We also extract from SDC information on various bond characteristics (coupon rate, maturity, bond rating, callability, convertibility, syndicated or not, public or private, total proceeds, market venue, ultimate parent country, and currency). Second, to calculate credit spreads, we collect zero-coupon government bond benchmarks for different countries, currencies, and maturities from Thomson Reuters Datastream and Bloomberg. Third, we compile analyst forecast characteristics from the Institutional Broker Estimate System (I/B/E/S). Fourth, we obtain firm characteristics (i.e., total assets, leverage, EBITA) from Compustat Global Vantage. Finally, to check whether a firm that has issued a bond is cross-listed on U.S. markets, we use data from Bank of New York, Citigroup, and JP Morgan. For a bond issue to be included in our sample, credit spread and bond data must be available in SDC, analyst data must be available in $\mathrm{I} / \mathrm{B} / \mathrm{E} / \mathrm{S}$, and financial information must be available in Compustat Global Vantage. This yields a final sample of 2,686 bonds issued by 394 firms between 1991 and 2007 that originate from 35 non-U.S. countries. In the following subsections we define the credit ratings and spreads variables, the analyst forecast variables, and the control variables. Table 1 summarizes the variable definitions and their sources.

\section{[Insert Table 1 about here]}

\subsection{Bonds ratings and credit spreads}

Our two dependent variables are bond ratings (RAT) and credit spreads (CS). In our empirical analysis, we first test the prediction in $\mathrm{H}_{1}$ by regressing bond ratings on an analyst forecast variable (defined below) and control variables. We then include the residuals (RATR) of this regression in credit spread regressions along with analyst forecast variables and control variables to

9 By ending our sample in 2007 we avoid having inferences confounded by the recent global crisis. 
test the prediction in $\mathrm{H}_{2} \cdot{ }^{10}$ We use the S\&P bond ratings reported in SDC. We convert the AAA to C letter ratings into numbers between 21 and one, respectively.

To calculate $\boldsymbol{C S}$, we first determine the offering yield to maturity of each bond. Then, for each bond, we match the offering yield to maturity to a government bond yield to maturity based on the currency denomination of the bond with equivalent maturity. Bonds issued by firms from Europe in Euros are matched with the respective government bond with the same maturity. For instance, a French bond issued in Euros is matched with the French government bond with the same maturity. Bonds issued before the introduction of the Euro are also matched with their respective government bonds. If the corporate bond maturity and the government bond maturity do not match, we use linear interpolation between the two closest government bond maturities. We then calculate $\boldsymbol{C S}$ as the difference between the corporate bond yield and the equivalent government bond yield.

\subsection{Analyst forecast variables}

Following Mansi et al. (2011), we use four variables as proxies for analyst forecast characteristics. These variables are calculated in the $11^{\text {th }}$ month of the fiscal year preceding the bond issue and are as follows. Forecast accuracy (ACCUR) is the negative absolute value of the difference between the median forecast and actual earnings per share (EPS) deflated by the stock price. Forecast dispersion (DISP) is the standard deviation of the most recently revised forecasts of all analysts deflated by the stock price. Forecast revision (REV) is the standard deviation of the difference between the median forecasts and the lagged median forecasts of all analysts deflated by the stock price. Finally, analyst forecast factor (FACTOR) is an index based on the three previous variables (ACCUR, DISP, and $\boldsymbol{R E V}$ ) that is calculated using principal component analysis. We construct FACTOR because the three previous analyst forecast variables are highly correlated. The Eigenvalue of FACTOR is 1.91 and the factor loadings are -0.53 on ACCUR, 0.63 on DISP, and 0.58 on $\boldsymbol{R E} \boldsymbol{V}$. Therefore, the lower the forecast accuracy (ACCUR), the higher the forecast dispersion (DISP), and the higher the forecast revision $(\boldsymbol{R E} \boldsymbol{V})$, the higher the analyst factor

10 This approach is standard in prior cost of debt literature (e.g., Mansi et al., 2004, 2011; Guedhami and Pittman, 2008). As explained in Section 4.1, this approach facilitates examining the marginal impact of analyst forecast characteristics on credit spreads above that captured by credit ratings. 
(FACTOR). For the sake of consistency, we reverse the sign of FACTOR and hence the higher its value, the higher the expected bond rating $(\boldsymbol{R A T})$ and the lower the expected credit spread $(\boldsymbol{C S}){ }^{11}$

\subsection{Control variables}

Given that $\boldsymbol{C S}$ is related to firms' default risk and bond characteristics, we include a large number of control variables shown in prior literature to determine CS to ensure that our results are not being driven by these variables. All firm-level control variables are constructed at the end of the fiscal year preceding the bond issue. The firm-level controls include: SIZE, the natural logarithm of total assets in millions of U.S. dollars; $\boldsymbol{L E} \boldsymbol{V}$, the leverage ratio, which is equal to total liabilities divided by total assets; PROFIT, the profitability ratio, which is equal to EBITA divided by total assets; GROWTH, the annual asset growth rate; and USLIST, a dummy variable equal to one if the firm is cross-listed on U.S. markets and zero otherwise.

Bond-level variables include: PUB, a dummy variable equal to one if the bond is issued on public markets and zero otherwise; $\boldsymbol{A G E}$, the natural logarithm of the bond's age, which is also equal to the natural logarithm of the bond's maturity; PROC, the natural logarithm of the bond's total proceeds in millions of U.S. dollars; CALL, a dummy variable equal to one if the bond is callable and zero otherwise; CONV, a dummy variable equal to one if the bond is convertible and zero otherwise; and $\boldsymbol{S Y N D}$, a dummy variable equal to one if the bond is syndicated and zero otherwise.

We also control for the following country-level variables: SOVRAT, S\&P’s letter sovereign credit ratings converted into numbers ranging from 22 (AAA with positive credit outlook) to zero (C with negative credit outlook); INTDB, international debt securities (amount outstanding) as a share of GDP; $\boldsymbol{C R B U R}$, a dummy variable equal to one if either a public registry or a private credit bureau operates in the country, and zero otherwise; CREDR, the creditor rights index of the ultimate parent country; and ENFOR, the debt enforcement efficiency index of the ultimate parent country.

\subsection{Descriptive statistics}

Table 2 provides descriptive statistics by country for all the variables used in our main regressions. In our sample, each firm has issued 6.8 bonds on average. Firms from Germany, Japan, and the U.K. dominate our sample with 672, 547, and 373 bond issues, respectively. Firms from

\footnotetext{
${ }^{11}$ As an additional variable, we also use the number of analysts (NUMEST) who provide forecasts.
} 
Greece have the highest average credit spread (3.97\%), while firms from Taiwan have the lowest average credit spread (0.12\%).

\section{[Insert Table 2 about here]}

Table 3 reports descriptive statistics for our regression variables for the sample of 2,686 bond issues of 394 firms between 1991 and 2007. The average (median) credit spread in our sample is 117 (73) basis points, indicating that the credit spread is highly skewed to the right. The average rating of bonds in our sample is between A- and A, the median rating is A-, and $90 \%$ of our bonds are investment grade. On average, 21 analysts provide forecasts about issuing firms, suggesting that our sample mostly consists of large firms (average total assets is $\$ 60.3$ million). Further, $82.1 \%$ of firms that issued a bond are cross-listed on U.S. markets through ADRs, 91\% of sample firms issued public bonds, and $17.4 \%$ of all issued bonds are callable.

\section{[Insert Table 3 about here]}

Table 4 reports Pearson correlation coefficients among the main variables used in the regression analysis. As a first test of our predictions in $\mathrm{H}_{1}$ and $\mathrm{H}_{2}$, we find that the credit spread is negatively correlated at the $1 \%$ level with forecast accuracy (ACCUR) and positively correlated at the $1 \%$ level with both forecast dispersion (DISP) and forecast revision (REV). The correlations also show that credit ratings $(\boldsymbol{R A T})$ are positively correlated at the $1 \%$ level with forecast accuracy (ACCUR) and negatively correlated at the $1 \%$ level with both forecast dispersion (DISP) and forecast revision ( $\boldsymbol{R E V}$ ). In addition, Table 4 shows that the analyst forecast variables are highly correlated, which motivates our use of principal components analysis to construct the analyst factor index. Providing further support for $\mathrm{H}_{1}$ and $\mathrm{H}_{2}$, the correlation analysis indicates that a higher analyst factor (i.e., higher forecast accuracy (ACCUR), lower forecast dispersion (DISP), and lower forecast revision $(\boldsymbol{R E} \boldsymbol{V})$ ) is associated with higher credit ratings and lower credit spreads. In the multivariate regression analysis in the next section, we more formally examine in the presence of firm-level, bond-level, as well as country-level control variables whether bonds' credit ratings and spreads are related to analyst forecast characteristics.

\section{[Insert Table 4 about here]}




\section{Empirical results}

\subsection{Regression models}

To test the predictions in $\mathrm{H}_{1}$ and $\mathrm{H}_{2}$, we estimate the following two regression models:

$$
\begin{aligned}
& \boldsymbol{R A T}=\alpha+\beta_{1} \text { Analyst Activity }+\beta_{2} \text { NUMEST }+\beta_{3} \text { SIZE }+\beta_{4} L E V+\beta_{5} \text { PROFIT }+\beta_{6} \text { GROWTH } \\
& +\beta_{7} U S L I S T+\beta_{8} P U B+\beta_{9} A G E+\beta_{9} P R O C+\beta_{10} C A L L+\beta_{11} C O N V+\beta_{12} S Y N D \\
& +\beta_{13} \text { OVRAT }+\beta_{14} N T D B+\beta_{15} C R B U R+\beta_{16} C R E D R+\beta_{17} E N F O R+\varepsilon \\
& \boldsymbol{C S}=\gamma+\delta_{1} \text { Analyst Activity }+\delta_{2} N U M E S T+\delta_{3} S I Z E+\delta_{4} L E V+\delta_{5} \text { PROFIT }+\delta_{6} G R O W T H \\
& +\delta_{7} U S L I S T+\delta_{8} P U B+\delta_{9} A G E+\delta_{10} P R O C+\delta_{11} C A L L+\delta_{12} C O N V+\delta_{13} S Y N D \\
& +\delta_{14} R A T R+\delta_{15} \text { OVRAT }+\delta_{16} N T D B+\delta_{17} C R B U R+\delta_{18} C R E D R+\delta_{19} \text { ENFOR }+\varepsilon
\end{aligned}
$$

where $\boldsymbol{R} \boldsymbol{A T}$ and $\boldsymbol{C S}$ are a firm's bond rating and credit spread, respectively, and Analyst Activity is one of the measures capturing analyst activity (ACCUR, DISP, REV, and FACTOR). All regressions include control variables as defined in Section 3.4 in addition to industry and year fixed effects. We estimate our models using pooled OLS. In all regressions, we address potential crosssectional correlation within firms by relying on robust standard errors that adjust for such clustering.

Our research suggests that analyst forecast properties can influence debt pricing directly through yield spreads and indirectly through credit ratings. If credit ratings perfectly impound the information contained in analyst forecasts, then bond spreads will not be influenced by such forecasts. However, prior research implies that although corporate governance affects bond ratings, yield spreads still absorb a lingering effect (e.g., Guedhami and Pittman, 2008; Mansi et al., 2011). Our research design therefore seeks to assess this lingering effect. In other words, we aim to show whether bondholders value analyst forecasts beyond credit rating agencies. Accordingly, in Equation (2) we control for the residual (RATR) obtained from regression Equation (1). To the extent that credit ratings already incorporate firm-specific information, including the impact of analyst forecast variables, the residual $\boldsymbol{R} \boldsymbol{A} \boldsymbol{T} \boldsymbol{R}$ summarizes the unique information value in credit ratings that is not captured by the other explanatory variables.

\subsection{The effect of analyst forecast properties on credit ratings}

We begin by examining the relationship between credit ratings and analyst forecasts (Equation (1)). Table 5 reports estimation results for several specifications of Equation (1). The 
explanatory power is generally very good, with an adjusted $\mathrm{R}^{2}$ around $58 \%$. We are interested in the coefficients on the analyst activity proxies, ACCUR, DISP, and $\boldsymbol{R E V}$. In Models 1 to 3, which include these three variables separately, we find evidence at the $1 \%$ level that forecast accuracy is positively related to credit ratings, and forecast dispersion and forecast revision are negatively related to credit ratings. When we include the three analyst forecast variables together in Model 4, forecast revision becomes insignificantly related to credit ratings, while the other two variables continue to load with the expected signs at the $1 \%$ level. This result is due to the high correlation between the three forecast variables and suggests that they are likely capturing the same information. In Model 5, we find that the analyst forecast factor (FACTOR) is significantly positively related to credit ratings. Taken together, these findings are consistent with our first hypothesis $\left(\mathrm{H}_{1}\right)$ and confirm evidence in Mansi et al. (2011) that various analyst forecast characteristics, and an analyst factor, are significantly related to credit ratings for bonds issued by U.S. firms. Our analysis thus extends Mansi et al.’s (2011) findings to bonds issued worldwide by non-U.S. firms in different currencies.

Turning to the other control variables, Table 5 shows that the number of analysts is not significantly related to credit ratings. All statistically significant control variables generally exhibit the expected signs. For instance, bonds issued by larger companies (SIZE), companies with a higher

profitability ratio (PROFIT), and companies that are cross-listed on the U.S. markets (USLIST) as well as public bonds (PUB) have higher credit ratings, while bonds issued by companies with a high leverage ratio $(L E V)$, callable bonds (CALL), and syndicated bonds (SYND) have lower credit ratings.

\section{[Insert Table 5 about here]}

\subsection{The effect of analyst forecast properties on credit spreads}

In this section, we examine the relationship between credit spreads and analyst forecasts. Table 6 reports the estimation results for several specifications of Equation (2), which include industry and year dummy effects. Across all specifications in the table, we include the residual (RATR) from the ratings regression on the analyst forecast factor and firm-, bond-, and country-level control variables, which reflects the information in bond ratings not affected by the other control variables, given that the residual is orthogonal to these variables. Models 1 through 3 consider the 
analyst forecast proxies ACCUR, DISP, and $\boldsymbol{R E} \boldsymbol{V}$ in turn. The results show that forecast accuracy is negatively related to the credit spread, and forecast dispersion and forecast revision are positively related to the credit spread, all significant at the $1 \%$ level. These results are consistent with our second hypothesis $\left(\mathrm{H}_{2}\right)$. The effects are also economically significant: on average, a 1\% increase in analyst accuracy (ACCUR) lowers firms' debt financing costs by $0.01 * 6.973 \approx 6.9$ basis points, a one-standard-deviation (0.012) increase in analyst dispersion (DISP) increases firms' cost of debt by $0.012 * 15.230 \approx 18.27$ basis points, and a one-standard-deviation (0.006) increase in analyst revision $(\boldsymbol{R E V})$ increases the credit spread by $0.006 * 15.931 \approx 9.55$ basis points. To put these estimates in perspective, the mean (median) yield spread in our sample is 117 (73) basis points. Similar to Model 4 in Table 5, when we include the three analyst forecast variables in the same regression (Model 4), forecast revision becomes statistically insignificant, which again is due to the high correlation among all three analyst forecast measures. Our analyst dispersion result is consistent with Güntay and Hackbarth's (2010) finding that forecast dispersion is significantly positively related to the credit spread of U.S. firms. The authors report in their baseline regression that a one-standard-deviation increase in forecast dispersion increases the credit spread by roughly 13.78 basis points. Our results are also consistent with Mansi et al.’s (2011) finding that the credit spread is positively related to forecast dispersion, and extend their results by showing that forecast accuracy is valued by bondholders in international markets. Our paper thus extends the findings in Güntay and Hackbarth (2010) and Mansi et al. (2011) to bonds issued worldwide by non-U.S. firms in different currencies.

In Model 5 we also find that the analyst forecast factor (FACTOR) is negatively related to the credit spread, significant at the $1 \%$ level. Underscoring its first-order economic importance, this coefficient estimate implies that a one-standard-deviation increase (by construction the standard deviation is one) in the analyst forecast factor decreases the credit spread by $12.4 \%$, or by $0.124 * 1.168 \approx 14.48$ basis points, as the average credit spread is $1.168 \%$. This result lends further support to our second hypothesis $\left(\mathrm{H}_{2}\right)$ and is in line with Mansi et al.'s (2011) finding that a onestandard-deviation change in the analyst forecast factor changes the credit spread by $11.2 \%$. We contribute to this line of research by showing that analysts' informational role is important in international markets.

Reinforcing the ratings evidence in Table 5, Table 6 shows that the number of analysts does not impact corporate bond yield spreads on international credit markets. We generally find that the 
firm-, bond-, and country-level control variables have the expected signs. For example, bonds issued by larger firms, firms with a higher profitability ratio, firms that are cross-listed on the U.S. markets, public bonds, and bonds with a higher residual rating have a lower credit spread. However, bonds issued by firms with higher asset growth and callable bonds have a higher credit spread. We also find that firms in countries with a higher sovereign credit rating, with a lower share of international debt securities to GDP, with a public registry or private credit bureau, and with a higher debt enforcement efficiency index have a lower credit spread.

\section{[Insert Table 6 about here]}

\subsection{Sensitivity analyses}

To check the robustness of our results, we conduct a battery of sensitivity tests as reported in Table 7. We first regress the credit spread (CS) on the analyst forecast factor (FACTOR) and the firm-, bond-, and country-level control variables using different subsamples (Models 1 through 6). We then conduct an out-of-sample robustness check to examine the relationship between the analyst forecast factor and credit spreads using bonds issued by U.S. firms and bonds issued by U.S. firms in U.S. dollars (Models 7 and 8, respectively).

\section{[Insert Table 7 about here]}

In Models 1 and 2, we examine whether the currency and the use of different benchmarks in computing the credit spread impacts our results by considering U.S. dollar-denominated bonds in Model 1 and Euro-denominated bonds in Model 2. As the results show, the analyst forecast factor is significantly negatively related to the credit spread, suggesting that our results are not driven by the choice of benchmark we use or by the currency of denomination.

In Model 3, we assess whether the Asian financial crisis impacts our results by excluding bonds issued during the 1998 Asian crisis year. The results show that the analyst forecast factor continues to load negative and significant and the control variables have the expected signs. Next, in Model 4 we exclude firms from Germany, Japan, and the U.K. to address the concern that some countries that dominate our sample might drive our results. The results indicate that these countries do not drive our results since the analyst forecast factor remains significantly negatively related to 
yield spreads. In addition, to assess whether our results are driven by a country's legal origin, we split our sample into bonds issued by firms in civil law and common law countries and report the results in Models 5 and 6, respectively. The analyst forecast factor again loads significantly in both models, and hence we conclude that analyst forecasts impact the credit spread independent of the country of origin's legal regime.

To ensure that our results are not sample-specific, do not depend on specific countries and currencies, and are consistent with previous research, we perform out-of-sample estimation using bonds issued by U.S. firms. Models 7 and 8 of Table 7 report estimation results using bonds issued by U.S. firms and bonds issued by U.S. firms in U.S. dollars, respectively. Using 10,036 U.S. bonds issued between 1991 and 2007, we find that the analyst forecast factor is strongly significantly negatively related to the firm's cost of debt. Model 7 shows that a one-standard-deviation (by construction it is equal to one) increase in the analyst forecast factor decreases the firm's cost of debt by $18.7 \%$. To ensure that the use of different benchmarks in computing the credit spread do not affect our results, in Model 8 we only consider bonds issued by U.S. firms in U.S dollars. Economically, we find that a one-standard-deviation increase in the analyst forecast factor decreases the firm's cost of debt by $19.3 \%$. This out-of-sample evidence reinforces our findings on the role of financial analysts in credit markets and lends strong support to earlier U.S. evidence in Mansi et al. (2011).

\section{Do financial analysts mitigate the effect of weak institutions?}

Our study is motivated by prior U.S. evidence that financial analysts play an informational role as reflected in a lower cost of debt financing. Our cross-country evidence suggests that the role of analysts as information intermediaries extends to an international setting. As a natural extension, we gauge the impact of countries' institutional infrastructure on the link between analyst forecast properties and debt pricing $\left(\mathrm{H}_{3}\right)$. More specifically, we examine whether analysts have a greater effect on credit spreads when institutions are weak. To examine this prediction we re-estimate Equation (2) for subsamples of strong and weak institutional environments. ${ }^{12}$

\footnotetext{
12 This design benefits from avoiding multicollinearity complications stemming from high correlations between the test variables and their interaction terms, especially when the interactions involve a dummy variable (e.g., Lang et al., 2004; Guedhami et al., 2009).
} 
We consider a comprehensive set of proxies for the institutional environment motivated by La Porta et al. (1998) and Dyck and Zingales (2004). Our first proxy is creditor rights protection (CREDITOR RIGHTS), which is derived from Djankov et al. (2007), who construct an index of the legal rights of creditors in the event of bankruptcy that closely resembles the index originally developed by La Porta et al. (1998). This index varies yearly over the period 1978-2003 and is the sum of four subcomponents. ${ }^{13}$ Our second proxy is the degree of freedom of the press (PRESS FREEDOM), which captures the extent of public opinion pressure in the country and comes from Dyck and Zingales (2004). ${ }^{14}$ We next include La Porta et al.'s (1998) rule of law index (RULEofLAW), which is computed based on law and order data from International Country Risk Guide (ICRG) over the period 1982-1995. This index measures the strength and impartiality of the legal system (the law subcomponent) as well as popular observance of the law (the order subcomponent), and ranges between 0 and 6 with higher values indicating stronger protection. Our fourth proxy is the risk of contract repudiation by the government (REPUDIATION), which we derive from La Porta et al.'s (1998: p. 1125) database. This variable measures the risk of a modification in a contract "taking the form of a repudiation, postponement, or scaling down" caused by "budget cutbacks, indigenization pressure, a change in government, or a change in government economic and social priorities.” Finally, we include the risk of expropriation by the government (EXPROPRIATION), which is also derived from La Porta et al. (1998) and captures the risk of property confiscation or forced nationalization. Both REPUDIATION and EXPROPRIATION vary from 0 to 10, with higher scores indicating lower risk.

Table 8 reports the results of these split-sample tests. The main insight that emerges from this analysis is that the analyst forecast factor (FACTOR) is strongly significantly negative in all models (except for Model 8), suggesting that analyst activity matters to bondholders across weak and strong institutional environments. However, when examining the magnitude of the coefficient on FACTOR across the subsamples of weak and strong institutions, we generally find that the effect of analyst activity is more important in the former subsample. Lending additional support to the prediction in

\footnotetext{
13 The four subcomponents reflect whether 1) secured creditors are able to seize their collateral when reorganization is approved, 2) secured creditors are the first to be paid from liquidation proceedings, 3) whether creditors' consent is required for reorganization, as opposed to debtors seeking protection from creditors by filing for rehabilitation, and 4) whether creditors or an administrator are responsible for running the business during reorganization.

${ }^{14}$ Dyck and Zingales (2004) argue that the media play an important role in uncovering misconduct by insiders and informing market participants of such activities.
} 
$\mathrm{H}_{3}$, we find that the coefficient on FACTOR is statistically different between the weak and strong institution subsamples for all five conditioning variables (CREDITOR RIGHTS, PRESS FREEDOM, RULEOfLAW, REPUDIATION, and EXPROPRIATION). It is important to note that analyst following, which is largely insignificant in Tables 5 and 6, becomes statistically significant in the subsample of countries with weak institutions, reinforcing the economic importance of FACTOR in these environments. In summary, the findings in Table 8 suggest that the importance of analyst forecast characteristics to debt pricing is more pronounced in environments with weak institutions, consistent with a substitution governance role between financial analysts and countrylevel governance institutions.

\section{[Insert Table 8 about here]}

\section{Conclusions}

Information asymmetry between firm insiders and outside investors suggests that financial analysts may be associated with an important role as information intermediaries. Indeed, in producing and disseminating information, analysts reduce information asymmetry problems between firms and market participants as well as agency problems by increasing the monitoring of managerial behavior and market discipline. While substantial research focuses on the value of analysts to shareholders, recent research provides evidence from the U.S. that bondholders price the information implied by analysts' activities above and beyond that implied by credit rating agencies (Mansi et al., 2004). However, the literature has little to say about the role of analysts in international credit markets, where information and agency problems are more severe compared to the U.S.

To fill this gap in the literature, in this paper we investigate the link between various analyst forecast characteristics (forecast dispersion, forecast accuracy, forecast revision, and their principal component score) and the cost of debt financing for a large sample of 2,686 bond issues from a diversified sample of 35 countries. Our results suggest that analyst forecast characteristics are associated with significantly lower bond yield spreads even after controlling for bond- and firm-level control variables as well as country-level institutional factors. In addition, we find that the role of analysts in financial markets persists in countries with weak and strong governance institutions, although the economic magnitude of these effects is more important in the former. Taken together, 
these results build on prior U.S. evidence in Mansi et al. (2004) and imply that the value of the information contained in analyst forecast properties extends to international credit markets. 


\section{References}

Anderson, R., Sattar, M., Reeb, D. "Founding Family Ownership and the Agency Cost of Debt." Journal of Financial Economics, (2003): 68, 263-285.

Ashbaugh-Skaife, H., Collins, D., LaFond, R. "The Effects of Corporate Governance on Firm Credit Ratings.” Journal of Accounting and Economics, (2006): 42, 203-243.

Avramov, D., Chordia, T., Jostova, G., Philipov, A. "Dispersion in Analysts’ Earnings Forecasts and Credit Rating.” Journal of Financial Economics, (2009): 91, 83-101.

Bessembinder, H., Maxwell, W. "Markets: Transparency and the Corporate Bond Market.” Journal of Economic Perspectives, (2008): 22, 217-234.

Bhojraj, S., Sengupta, P. "Effect of Corporate Governance on Bond Ratings and Yields: The Role of Institutional Investors and Outside Directors.” Journal of Business, (2003): 76, 455-475.

Boubakri, N., Ghouma, H. "Control/Ownership Structure, Creditor Rights Protection, and the Cost of Debt Financing: International Evidence.” Journal of Banking and Finance, (2010): 34, 24812499.

Brockman, P., Chung, D. "The Inter-Temporal Behavior of Informed and Uninformed Traders." Review of Quantitative Finance and Accounting, (2003): 21, 251-265.

Bushman, R., Piotroski, J. "Financial Reporting Incentives for Conservative Accounting: The Influence of Legal and Political Institutions.” Journal of Accounting and Economics, (2006): 42, 107-148.

Bushman, R., Pitorski, E., Smith, A. "What Determines Corporate Transparency?” Journal of Accounting Research, (2004): 42, 207-252.

Callen, J., Livnat, J., Segal, D. "The Impact of Earnings on the Pricing of Credit Default Swaps.” Accounting Review, (2009): 84, 1363-1394.

Chan, K., Hameed, A. "Stock Price Synchronicity and Analyst Coverage in Emerging Markets." Journal of Financial Economics, (2006): 80, 115-147.

Chang, J., Khanna, T., Palepu, K. “Analyst Activity around the World.” Harvard Business School Working Paper, (2001): No. 01-061, April 2001.

Cheng, M., Subramanyam, K. “Analyst Following and Credit Ratings.” Contemporary Accounting Research 25, (2008): 1007-1044.

Claessens, S., Djankov, S., Fan, P., Lang, H. "Disentangling the Incentive and Entrenchment Effects of Large Shareholdings.” Journal of Finance, (2002): 62, 2741-2771.

Collin-Dufresne, P., Goldstein, R., Martin, S. "The Determinants of Credit Spread Changes." Journal of Finance, (2001): 56, 2177-2207.

DeFond, M., Zhang, J. "The Timeliness of the Bond Market Reaction to Bad News Earnings Surprises.” Contemporary Accounting Research, (2013): forthcoming.

Djankov, S., McLiesh, C., Shleifer, A. "Private Credit in 129 Countries." Journal of Financial Economics, (2007): 84, 299-329.

Djankov, S., Hart, O., McLiesh, C., Shleifer, A. “Debt Enforcement around the World.” Journal of Political Economy, (2008): 116, 1105-1149.

Duffie, D., Lando, D. "Term Structures of Credit Spreads with Incomplete Accounting Information.” Econometrica, (2001): 69, 633-664.

Dyck, A., Zingales, L. "Private Benefits of Control: An International Comparison." Journal of Finance, (2004): 59, 537-600.

Easton, P., Monahan, S., Vasvari, F. "Some Initial Evidence on the Role of Accounting Earnings in the Bond Market.” Journal of Accounting Research, (2009): 47, 721-766. 
Ellul, A., Guntay, L., Lel, U. "External Governance and Debt Agency Costs of Family Firms." Working Paper, 2007.

Francis, J., LaFond, R., Olsson, P., Schipper, K. “The Market Pricing of Accrual Quality.” Journal of Accounting and Economics, (2005): 39, 295-327.

Francis, J., Nanda, D., Olsson, P. "Voluntary Disclosure, Earnings Quality, and Cost of Capital." Journal of Accounting Research, (2008): 46, 53-99.

Freedom House. "Annual freedom in the world survey: Political rights and Civil Liberties Rating 1972-2006.” 2007. www.freedomhouse.org.

Gozzi, J., Levine, R., Martinez Peria, M., Schmukler, S. "How Firms Use Domestic and International Corporate Bond Markets.” NBER Working Paper, 2012.

Guedhami, O., Pittman, J. "The Importance of IRS Monitoring to Debt Pricing in Private Firms.” Journal of Financial Economics, (2008): 90, 38-58.

Guedhami, O., Pittman, J., Saffar, W. "Auditor Choice in Privatized Firms: Empirical Evidence on The Role of State And Foreign Owners.” Journal of Accounting and Economics, (2009): 48, 151-171.

Güntay, L., Hackbarth, D. “Corporate Bond Credit Spreads and Forecast Dispersion.” Journal of Banking and Finance, (2010): 34, 2328-2345.

Hope, O. "Disclosure Practices, Enforcement of Accounting Standards, and Analysts' Forecast Accuracy: An International Study.” Journal of Accounting Research, (2003): 41, 235-273.

Islam, S., Mozumdar, A. "Financial Market Development and the Importance of Internal Cash: Evidence from International Data.” Journal of Banking and Finance, (2007): 31, 641-658.

Khurana, I., Pereira, R., Martin, X. "Firm Growth and Disclosure: An Empirical Analysis.” Journal of Financial and Quantitative Analysis, (2006): 41, 357-380.

Klock, M., Mansi, S., Maxwell, W. “Does Corporate Governance Matter to Bondholders?” Journal of Financial and Quantitative Analysis, (2005): 40, 693-719.

Knyazeva, D. “Corporate Governance, Analyst Following, and Firm Behavior.” Working Paper, University of Rochester, 2008.

La Porta, R., Lopez-de-Silanes, F., Shleifer, A., Vishny, R. “Law and Finance.” Journal of Political Economy, (1998): 106, 1113-1155.

Lang, M., Lins, K., Miller, D. "Concentrated Control, Analyst Following, and Valuation: Do Analysts Matter Most When Investors Are Protected Least?” Journal of Accounting Research, (2004): 42, 589-623.

Lang, M., Lundholm, R. “Corporate Disclosure Policy and Analyst Behavior.” Accounting Review, (1996): 71, 467-492.

Li, N. "Negotiated Measurement Rules in Debt Contracts.” Journal of Accounting Research, (2010): 48, 1103-1144.

Love, I. "Financial Development and Financing Constraints: International Evidence from the Structural Investment Model.” Review of Financial Studies, (2003): 16, 765-791.

Mansi, S., Maxwell, W., Miller, D. "Does Auditor Quality and Tenure Matter to Investors: Evidence from the Bond Market.” Journal of Accounting Research, (2004): 42, 755-793.

Mansi, S., Maxwell, W., Miller, D. “Analyst Forecast Characteristics and the Cost of Debt.” Review of Accounting Studies, (2011): 16, 116-142.

Miller, D., Puthenpurackal, J. "The Costs, Determinants, and Wealth Effects of International Capital Raising: Evidence from Public Yankee Bonds.” Journal of Financial Intermediation, (2002): 11, 455-485

Miller, M. “Debt and Taxes.” Journal of Finance, (1977): 32, 261-75. 
Morck, R., Yeung, B., Yu, W. "The Information Content of Stock Markets: Why Do Emerging Markets Have Synchronous Stock Price Movements?” Journal of Financial Economics, (2000): 58, 215-238.

Pittman, J., Fortin, S. "Auditor Choice and the Cost of Debt Capital for Newly Public Firms." Journal of Accounting and Economics, (2004): 37, 113-136.

Ramnath, S., Rock, S., Shane, P. "A Review of Research Related to Financial Analysts' Forecasts and Recommendations.” Foundations and Trends in Finance, (2008): 2-4, 311-421.

Sengupta, P. "Corporate Disclosure Quality and the Cost of Debt.” Accounting Review, (1998): 73, 459-474.

Shleifer, A., Vishny, R. “A Survey of Corporate Governance.” Journal of Finance, (1997): 52, 737783.

Yu, F. “Accounting Transparency and the Term Structure of Credit spreads.” Journal of Financial Economics, (2005): 75, 53-84. 
Table 1: Variable definitions and sources

\begin{tabular}{|c|c|c|}
\hline Variable & Definition & Source \\
\hline \multicolumn{3}{|c|}{ Panel A: Bond rating and credit spread variables } \\
\hline CS & $\begin{array}{l}\text { The credit spread (in percentage), which is defined as the difference between the corporate yield to maturity and a governmental bond yield } \\
\text { to maturity based on the currency denomination of the bond and an equivalent maturity. }\end{array}$ & Securities Data Company \\
\hline RAT & $\begin{array}{l}\text { The S\&P bond rating reported in Securities Data Company. We convert the AAA to C letter rating into a number rating between } 21 \text { and } \\
\text { one, respectively. }\end{array}$ & Securities Data Company \\
\hline RATR & The residuals from regressing bond ratings on an analyst forecast variable and control variables. & Authors’ specification \\
\hline \multicolumn{3}{|c|}{ Panel B: Analyst forecast variables } \\
\hline ACCUR & $\begin{array}{l}\text { Forecast accuracy, defined as the negative absolute value of the difference between the median forecast and actual earnings per share (EPS) } \\
\text { deflated by the stock price. }\end{array}$ & $\begin{array}{l}\text { I/B/E/S and authors' } \\
\text { specifications }\end{array}$ \\
\hline DISP & Forecast dispersion, defined as the standard deviation of forecasts of all analysts deflated by the stock price. & $\begin{array}{l}\text { I/B/E/S and authors' } \\
\text { specifications }\end{array}$ \\
\hline$R E V$ & $\begin{array}{l}\text { Forecast revision, defined as the standard deviation of the recently revised forecasts of all analysts deflated by the stock price. In other } \\
\text { words, it is equal to the standard deviation of the difference between the median forecast and the lagged median forecast of all analysts over } \\
\text { the stock price. }\end{array}$ & $\begin{array}{l}\text { I/B/E/S and authors' } \\
\text { specifications }\end{array}$ \\
\hline FACTOR & $\begin{array}{l}\text { Analyst factor. As the three previous analyst forecast variables are highly correlated, we employ principal component analysis to form an } \\
\text { index based on these three variables (ACCUR, DISP, and REV). }\end{array}$ & $\begin{array}{l}\text { I/B/E/S and authors' } \\
\text { specifications }\end{array}$ \\
\hline NUMEST & Number of analysts. & $\begin{array}{l}\text { I/B/E/S and authors' } \\
\text { specifications }\end{array}$ \\
\hline \multicolumn{3}{|c|}{ Panel C: Control variables } \\
\hline \multicolumn{3}{|c|}{ Firm-level control variables } \\
\hline SIZE & The natural logarithm of total assets in millions of U.S. dollars. & COMPUSTAT \\
\hline$L E V$ & The leverage ratio, which is equal to total liabilities divided by total assets. & COMPUSTAT \\
\hline PROFIT & The profitability ratio, which is equal to EBITA divided by total assets. & COMPUSTAT \\
\hline GROWTH & The annual asset growth rate. & COMPUSTAT \\
\hline USLIST & A dummy variable equal to one if the firm is cross-listed on U.S. markets, and zero otherwise. & $\begin{array}{l}\text { Bank of New York, Citigroup, } \\
\text { and JP Morgan }\end{array}$ \\
\hline \multicolumn{3}{|c|}{ Bond-level control variables } \\
\hline$P U B$ & A dummy variable equal to one if the bond is issued on public markets, and zero otherwise. & Securities Data Company \\
\hline$A G E$ & The natural logarithm of the bond's age, which is also equal to the natural logarithm of the bond's maturity. & Securities Data Company \\
\hline PROC & The natural logarithm of the total proceeds in millions of U.S. dollars. & Securities Data Company \\
\hline$C A L L$ & A dummy variable equal to one if the bond is a callable bond, and zero otherwise. & Securities Data Company \\
\hline CONV & A dummy variable equal to one if the bond is a convertible bond, and zero otherwise & Securities Data Company \\
\hline SYND & A dummy variable equal to one if the bond is syndicated, and zero otherwise. & Securities Data Company \\
\hline \multicolumn{3}{|c|}{ Institutional control variables } \\
\hline SOVRAT & Standard \& Poor's sovereign credit ratings converted into numbers ranging from 21 (AAA) to zero (D). & Standard and Poor's website \\
\hline INTDB & International debt securities (amount outstanding) as a share of GDP. & World Bank \\
\hline CRBUR & $\begin{array}{l}\text { A dummy variable equal to one if either a public registry or a private credit bureau operates in the country, and zero otherwise. A public } \\
\text { registry is defined as a database owned by public authorities (usually the Central Bank or Banking Supervisory Authority) that collects } \\
\text { information on the standing of borrowers in the financial system and makes this information available to financial institutions. A private } \\
\text { credit bureau is defined as a private commercial firm or non-profit organization that maintains a database on the standing of borrowers in } \\
\text { the financial system, and its primary role is to facilitate the exchange of information among banks and financial institutions. }\end{array}$ & Djankov et al. (2007) \\
\hline
\end{tabular}




\section{ENFOR}

The creditor rights index of the ultimate parent country.

The debt enforcement efficiency index of the ultimate parent country.

Djankov et al. (2008)

An index of freedom of the press. Higher scores mean higher freedom of the print and broadcast media in a country. The index ranges from zero (free) to 100 (not free).

Rule of law

Measure on a scale from zero to six (the best outcome). The index of Law and Order is an assessment of the strength and impartiality of the legal system, and of popular observance of the law.

Repudiation

The government repudiation of contracts, scored from zero to ten, is a measure of the risk of a government modifying a contract by repudiating, postponing, or scaling it down due to budget cuts, domestic pressures, change in government, or a change in domestic circumstances and priorities.

Expropriation
Expropriation, scored from zero to ten, is a measure of the risk of outright confiscation or forced nationalization.
Djankov et al. (2008)

Freedom House (2007)

International Country Risk

Guide (2010)

International Country Risk

Guide (2010)

International Country Risk Guide (2010) 
Table 2: Descriptive statistics by country

This table reports means for the main variables used in our main regressions. Table 1 provides the definitions and data sources for these variables. The sample period is $1991-2007$.

\begin{tabular}{|c|c|c|c|c|c|c|c|c|c|c|c|c|c|c|c|c|c|c|c|}
\hline Country & CS & RAT & ACCUR & DISP & REV & FACTOR & NUMEST & SIZE & LEV & PROFIT & GROWTH & USLIST & PUB & AGE & PROC & CALL & CONV & SYND & \# of obs. \\
\hline Argentina & 2.94 & 13.00 & -0.005 & 0.006 & 0.002 & 0.487 & 20.33 & 9.04 & 0.46 & 0.08 & 0.08 & 0.78 & 0.89 & 1.98 & 5.02 & 0.11 & 0.00 & 0.44 & 9 \\
\hline Australia & 1.27 & 14.20 & -0.014 & 0.003 & 0.002 & 0.411 & 12.07 & 8.15 & 0.57 & 0.08 & 0.14 & 0.80 & 0.57 & 2.16 & 4.81 & 0.15 & 0.00 & 0.66 & 94 \\
\hline Austria & 0.76 & 13.00 & -0.009 & 0.004 & 0.001 & 0.627 & 16.00 & 9.07 & 0.65 & 0.03 & -0.02 & 1.00 & 1.00 & 2.07 & 6.57 & 0.00 & 0.00 & 1.00 & 3 \\
\hline Belgium & 0.97 & 14.67 & -0.003 & 0.005 & 0.002 & 0.583 & 12.83 & 7.65 & 0.56 & 0.07 & 0.04 & 0.83 & 0.33 & 2.11 & 4.45 & 0.00 & 0.00 & 1.00 & 6 \\
\hline Brazil & 2.87 & 12.50 & -0.015 & 0.024 & 0.007 & -1.342 & 10.40 & 9.22 & 0.60 & 0.15 & 0.43 & 1.00 & 0.80 & 2.47 & 5.91 & 0.22 & 0.00 & 0.70 & 10 \\
\hline Canada & 2.21 & 11.95 & -0.012 & 0.011 & 0.006 & -0.316 & 14.02 & 8.47 & 0.63 & 0.05 & 0.20 & 0.59 & 0.77 & 2.40 & 5.51 & 0.72 & 0.00 & 0.81 & 304 \\
\hline Chile & 1.33 & 14.20 & -0.004 & 0.009 & 0.004 & 0.132 & 14.20 & 8.11 & 0.42 & 0.06 & 0.17 & 0.10 & 0.90 & 2.02 & 5.18 & 0.00 & 0.00 & 0.70 & 10 \\
\hline China & 3.13 & 11.00 & -0.004 & 0.003 & 0.001 & 0.827 & 12.00 & 6.39 & 0.61 & 0.06 & 0.59 & 0.00 & 1.00 & 1.95 & 5.30 & 0.00 & 0.00 & 0.00 & 1 \\
\hline Denmark & 0.89 & 15.50 & -0.002 & 0.003 & 0.001 & 0.904 & 14.00 & 7.23 & 0.64 & 0.07 & 0.02 & 0.00 & 0.25 & 2.21 & 5.16 & 0.00 & 0.00 & 0.25 & 4 \\
\hline Finland & 1.19 & 14.00 & -0.008 & 0.009 & 0.003 & 0.143 & 14.50 & 7.63 & 0.50 & 0.08 & -0.43 & 1.00 & 1.00 & 1.78 & 5.81 & 0.00 & 0.00 & 1.00 & 2 \\
\hline France & 1.16 & 14.41 & -0.020 & 0.012 & 0.004 & -0.239 & 22.31 & 10.44 & 0.75 & 0.05 & 0.00 & 0.83 & 0.95 & 1.81 & 5.86 & 0.10 & 0.02 & 0.71 & 221 \\
\hline Germany & 1.13 & 15.43 & -0.016 & 0.009 & 0.004 & -0.131 & 33.60 & 11.58 & 0.78 & 0.02 & 0.08 & 0.98 & 0.98 & 1.32 & 3.88 & 0.09 & 0.00 & 0.61 & 672 \\
\hline Greece & 3.97 & 9.50 & -0.072 & 0.035 & 0.007 & -3.412 & 5.88 & 7.57 & 0.62 & 0.09 & 0.10 & 0.25 & 0.25 & 2.11 & 5.12 & 0.75 & 0.00 & 0.38 & 8 \\
\hline Hong Kong & 1.78 & 14.47 & -0.015 & 0.007 & 0.003 & 0.118 & 25.53 & 9.62 & 0.50 & 0.10 & 0.17 & 0.89 & 0.74 & 2.25 & 5.79 & 0.11 & 0.00 & 0.84 & 19 \\
\hline Hungary & 1.28 & 12.00 & -0.051 & 0.025 & 0.005 & -2.130 & 8.00 & 9.00 & 0.55 & 0.16 & 0.07 & 1.00 & 1.00 & 1.61 & 6.80 & 0.00 & 0.00 & 1.00 & 1 \\
\hline India & 1.79 & 12.71 & -0.012 & 0.010 & 0.003 & -0.019 & 10.07 & 8.43 & 0.51 & 0.10 & 0.28 & 1.00 & 0.71 & 2.42 & 4.61 & 0.00 & 0.00 & 0.79 & 14 \\
\hline Indonesia & 2.87 & 10.67 & -0.016 & 0.012 & 0.005 & -0.490 & 13.67 & 6.72 & 0.51 & 0.17 & 0.19 & 0.33 & 0.67 & 1.84 & 5.25 & 0.00 & 0.00 & 0.67 & 3 \\
\hline Italy & 1.31 & 14.16 & -0.039 & 0.027 & 0.010 & -1.875 & 25.31 & 11.05 & 0.78 & 0.03 & 0.07 & 0.76 & 0.98 & 1.99 & 5.83 & 0.16 & 0.00 & 0.69 & 80 \\
\hline Japan & 0.39 & 17.17 & -0.008 & 0.005 & 0.004 & 0.324 & 12.47 & 11.05 & 0.77 & 0.02 & 0.02 & 0.97 & 0.97 & 1.73 & 4.81 & 0.04 & 0.00 & 0.35 & 547 \\
\hline Luxembourg & 0.74 & 14.00 & -0.029 & 0.003 & 0.002 & 0.109 & 6.00 & 9.02 & 0.54 & 0.06 & -0.05 & 0.00 & 1.00 & 1.64 & 6.33 & 0.00 & 0.00 & 1.00 & 4 \\
\hline Malaysia & 2.13 & 13.80 & -0.023 & 0.007 & 0.002 & 0.002 & 22.00 & 8.59 & 0.58 & 0.07 & 1.72 & 0.00 & 1.00 & 2.60 & 5.79 & 0.00 & 0.00 & 1.00 & 5 \\
\hline Mexico & 3.04 & 12.24 & -0.017 & 0.024 & 0.007 & -1.357 & 16.05 & 8.32 & 0.55 & 0.08 & 0.21 & 0.67 & 0.71 & 2.17 & 5.19 & 0.42 & 0.00 & 0.48 & 21 \\
\hline $\begin{array}{l}\text { Netherlands } \\
\text { New }\end{array}$ & 1.71 & 13.56 & -0.017 & 0.008 & 0.003 & 0.085 & 32.72 & 9.60 & 0.67 & 0.05 & 0.28 & 0.86 & 0.90 & 2.09 & 6.10 & 0.24 & 0.06 & 0.78 & 50 \\
\hline Zealand & 0.89 & 15.59 & -0.008 & 0.004 & 0.002 & 0.578 & 10.06 & 7.79 & 0.62 & 0.11 & 0.30 & 0.59 & 0.82 & 2.31 & 4.83 & 0.00 & 0.00 & 0.71 & 17 \\
\hline Norway & 1.34 & 13.20 & -0.010 & 0.010 & 0.002 & 0.110 & 24.60 & 8.93 & 0.71 & 0.14 & 0.12 & 0.00 & 1.00 & 2.59 & 5.36 & 0.20 & 0.00 & 1.00 & 5 \\
\hline Philippines & 3.69 & 9.67 & -0.012 & 0.006 & 0.003 & 0.259 & 16.17 & 8.15 & 0.59 & 0.06 & 0.19 & 0.17 & 1.00 & 2.22 & 5.12 & 0.08 & 0.00 & 1.00 & 12 \\
\hline Portugal & 0.63 & 15.71 & -0.010 & 0.008 & 0.002 & 0.269 & 16.86 & 9.25 & 0.71 & 0.07 & 0.05 & 0.86 & 1.00 & 2.23 & 6.71 & 0.00 & 0.00 & 0.86 & 7 \\
\hline Singapore & 3.21 & 8.50 & -0.027 & 0.008 & 0.008 & -0.771 & 15.83 & 7.34 & 0.43 & 0.00 & 0.06 & 1.00 & 0.67 & 2.16 & 5.49 & 0.75 & 0.00 & 0.50 & 6 \\
\hline South Africa & 2.63 & 10.67 & -0.012 & 0.007 & 0.004 & 0.100 & 6.33 & 7.84 & 0.66 & 0.02 & -0.10 & 1.00 & 0.67 & 2.59 & 5.73 & 1.00 & 0.00 & 0.67 & 3 \\
\hline Spain & 0.94 & 16.00 & -0.013 & 0.008 & 0.003 & 0.078 & 28.52 & 10.53 & 0.76 & 0.05 & 0.45 & 0.64 & 0.85 & 2.08 & 6.01 & 0.14 & 0.02 & 0.71 & 66 \\
\hline Sweden & 1.28 & 14.36 & -0.001 & 0.004 & 0.001 & 0.758 & 16.93 & 8.56 & 0.56 & 0.07 & 0.28 & 0.93 & 0.50 & 2.13 & 5.22 & 0.00 & 0.00 & 0.79 & 14 \\
\hline Switzerland & 1.05 & 17.34 & -0.010 & 0.006 & 0.002 & 0.319 & 23.98 & 10.04 & 0.64 & 0.08 & 0.10 & 0.91 & 0.97 & 1.73 & 5.40 & 0.09 & 0.00 & 0.69 & 58 \\
\hline Taiwan & 0.12 & 14.53 & -0.019 & 0.009 & 0.008 & -0.656 & 11.28 & 8.56 & 0.44 & 0.13 & 0.17 & 0.41 & 1.00 & 1.62 & 2.64 & 0.50 & 0.03 & 0.44 & 32 \\
\hline Thailand & 1.32 & 12.80 & -0.030 & 0.008 & 0.003 & -0.364 & 20.60 & 7.72 & 0.55 & 0.09 & 0.51 & 0.80 & 1.00 & 1.71 & 4.78 & 0.00 & 0.00 & 0.80 & 5 \\
\hline U.K. & 1.11 & 15.80 & -0.007 & 0.005 & 0.002 & 0.492 & 17.75 & 9.64 & 0.60 & 0.09 & 0.19 & 0.66 & 0.93 & 1.90 & 5.54 & 0.16 & 0.01 & 0.69 & 373 \\
\hline Total & 1.17 & 15.12 & -0.013 & 0.008 & 0.004 & 0.000 & 21.05 & 10.26 & 0.70 & 0.05 & 0.12 & 0.82 & 0.91 & 1.80 & 4.95 & 0.17 & 0.00 & 0.62 & 2,686 \\
\hline
\end{tabular}


Table 3: Descriptive statistics for regression variables

The table reports summary statistics for the variables used in our main regressions. Table 1 provides the definitions and data sources for these variables. The sample period is 1991-2007.

\begin{tabular}{|c|c|c|c|c|c|c|c|c|}
\hline & Mean & $\begin{array}{l}\text { Standard } \\
\text { Deviation }\end{array}$ & $\begin{array}{c}\text { Lower } \\
\text { Quartile }\end{array}$ & Median & $\begin{array}{c}\text { Upper } \\
\text { Quartile } \\
\end{array}$ & Min. & Max. & \# of obs. \\
\hline \multicolumn{9}{|c|}{ Bond rating and credit spread variables } \\
\hline CS & 1.168 & 1.432 & 0.336 & 0.730 & 1.443 & 0.003 & 21.977 & 2,686 \\
\hline RAT & 15.121 & 3.058 & 14.000 & 15.000 & 17.000 & 4.000 & 21.000 & 2,686 \\
\hline \multicolumn{9}{|c|}{ Analyst forecast variables } \\
\hline ACCUR & -0.013 & 0.021 & -0.017 & -0.005 & -0.002 & -0.188 & 0.000 & 2,665 \\
\hline DISP & 0.008 & 0.012 & 0.003 & 0.006 & 0.010 & 0.000 & 0.132 & 2,685 \\
\hline REV & 0.004 & 0.006 & 0.001 & 0.002 & 0.005 & 0.000 & 0.096 & 2,685 \\
\hline FACTOR & 0.000 & 1.380 & -0.341 & 0.320 & 0.788 & -15.217 & 1.147 & 2,663 \\
\hline NUMEST & 21.051 & 10.921 & 12.000 & 19.000 & 30.000 & 3.000 & 50.000 & 2,686 \\
\hline \multicolumn{9}{|c|}{ Firm-level control variables } \\
\hline SIZE & 10.264 & 1.555 & 9.221 & 10.794 & 11.419 & 3.952 & 12.433 & 2,686 \\
\hline LEV & 0.699 & 0.142 & 0.606 & 0.729 & 0.812 & 0.065 & 0.943 & 2,686 \\
\hline PROFIT & 0.048 & 0.058 & 0.018 & 0.042 & 0.074 & -0.866 & 0.319 & 2,686 \\
\hline GROWTH & 0.117 & 0.445 & -0.012 & 0.045 & 0.153 & -0.882 & 6.926 & 2,686 \\
\hline USLIST & 0.821 & 0.383 & 1.000 & 1.000 & 1.000 & 0.000 & 1.000 & 2,683 \\
\hline \multicolumn{9}{|c|}{ Bond-level control variables } \\
\hline PUB & 0.909 & 0.288 & 1.000 & 1.000 & 1.000 & 0.000 & 1.000 & 2,686 \\
\hline AGE & 1.804 & 0.751 & 1.386 & 1.946 & 2.303 & 0.000 & 3.466 & 2,686 \\
\hline PROC & 4.953 & 1.593 & 4.060 & 5.298 & 6.103 & 0.000 & 8.424 & 2,635 \\
\hline CALL & 0.174 & 0.379 & 0.000 & 0.000 & 0.000 & 0.000 & 1.000 & 2,610 \\
\hline CONV & 0.004 & 0.067 & 0.000 & 0.000 & 0.000 & 0.000 & 1.000 & 2,686 \\
\hline SYND & 0.616 & 0.486 & 0.000 & 1.000 & 1.000 & 0.000 & 1.000 & 2,686 \\
\hline \multicolumn{9}{|c|}{ Institutional control variables } \\
\hline SOVRAT & 20.137 & 1.994 & 20.000 & 21.000 & 21.000 & 3.000 & 21.000 & 2,686 \\
\hline INTDB & 0.320 & 0.230 & 0.104 & 0.287 & 0.496 & 0.010 & 1.932 & 2,686 \\
\hline CRBUR & 0.996 & 0.067 & 1.000 & 1.000 & 1.000 & 0.000 & 1.000 & 2,668 \\
\hline CREDR & 2.280 & 1.171 & 1.500 & 2.000 & 3.000 & 0.000 & 4.000 & 2,668 \\
\hline ENFOR & 76.812 & 19.571 & 57.000 & 90.700 & 93.200 & 13.400 & 96.100 & 2,668 \\
\hline
\end{tabular}


Table 4: Correlation coefficients

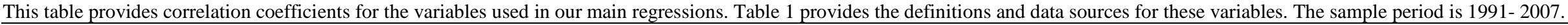

\begin{tabular}{|c|c|c|c|c|c|c|c|c|c|c|c|c|c|c|c|c|c|c|c|c|c|c|c|}
\hline & us & 武 & 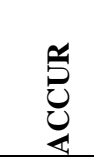 & $\frac{\tilde{0}}{\tilde{0}}$ & 空 & 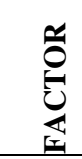 & 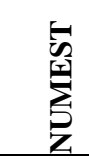 & 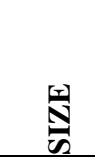 & 孛 & 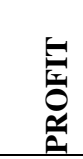 & $\begin{array}{l}\mathbf{T} \\
3 \\
0 \\
0 \\
0 \\
0\end{array}$ & $\begin{array}{l}\sqrt[5]{0} \\
\stackrel{5}{7} \\
0\end{array}$ & 定 & 资 & 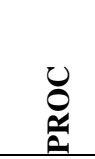 & 寻 & 忞 & $\sum_{\substack{\lambda \\
\text { s }}}$ & 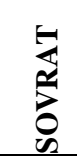 & 总 & 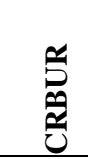 & $\begin{array}{l}\text { 号 } \\
\text { 空 } \\
\text { 先 }\end{array}$ & 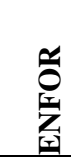 \\
\hline CS & 1.00 & & & & & & & & & & & & & & & & & & & & & & \\
\hline RAT & -0.63 & 1.00 & & & & & & & & & & & & & & & & & & & & & \\
\hline ACCUR & -0.21 & 0.24 & 1.00 & & & & & & & & & & & & & & & & & & & & \\
\hline DISP & 0.23 & -0.32 & -0.48 & 1.00 & & & & & & & & & & & & & & & & & & & \\
\hline REV & 0.16 & -0.24 & -0.32 & 0.56 & 1.00 & & & & & & & & & & & & & & & & & & \\
\hline FACTOR & -0.25 & 0.34 & 0.73 & -0.87 & -0.79 & 1.00 & & & & & & & & & & & & & & & & & \\
\hline NUMEST & -0.12 & 0.15 & -0.04 & 0.02 & -0.06 & 0.00 & 1.00 & & & & & & & & & & & & & & & & \\
\hline SIZE & -0.38 & 0.50 & 0.02 & -0.07 & 0.00 & 0.04 & 0.48 & 1.00 & & & & & & & & & & & & & & & \\
\hline LEV & -0.10 & 0.08 & -0.13 & 0.12 & 0.12 & -0.16 & 0.13 & 0.52 & 1.00 & & & & & & & & & & & & & & \\
\hline PROFIT & -0.07 & 0.09 & 0.19 & -0.19 & -0.25 & 0.26 & -0.03 & -0.29 & -0.47 & 1.00 & & & & & & & & & & & & & \\
\hline GROWTH & 0.22 & -0.15 & -0.07 & 0.00 & -0.01 & -0.02 & -0.06 & -0.17 & -0.11 & -0.03 & 1.00 & & & & & & & & & & & & \\
\hline USLIST & -0.25 & 0.30 & 0.05 & -0.09 & -0.06 & 0.09 & 0.23 & 0.49 & 0.24 & -0.07 & -0.15 & 1.00 & & & & & & & & & & & \\
\hline PUB & -0.27 & 0.29 & 0.05 & -0.04 & 0.00 & 0.04 & 0.17 & 0.35 & 0.16 & -0.10 & -0.07 & 0.17 & 1.00 & & & & & & & & & & \\
\hline AGE & 0.17 & -0.18 & 0.07 & -0.01 & -0.02 & 0.04 & -0.33 & -0.36 & -0.22 & 0.18 & 0.07 & -0.19 & -0.16 & 1.00 & & & & & & & & & \\
\hline PROC & 0.01 & -0.01 & 0.03 & 0.04 & -0.10 & 0.03 & -0.17 & -0.20 & -0.19 & 0.31 & 0.02 & -0.08 & -0.03 & 0.41 & 1.00 & & & & & & & & \\
\hline CALL & 0.41 & -0.45 & -0.03 & 0.11 & 0.09 & -0.10 & -0.19 & -0.37 & -0.16 & 0.06 & 0.10 & -0.13 & -0.24 & 0.31 & 0.12 & 1.00 & & & & & & & \\
\hline CONV & 0.06 & -0.09 & -0.07 & 0.08 & 0.03 & -0.08 & 0.03 & -0.06 & -0.02 & -0.03 & -0.01 & 0.03 & 0.02 & -0.03 & 0.02 & 0.07 & 1.00 & & & & & & \\
\hline SYND & 0.08 & -0.14 & 0.09 & -0.02 & 0.06 & 0.02 & 0.04 & -0.09 & -0.12 & 0.15 & 0.04 & -0.08 & 0.19 & 0.31 & 0.27 & 0.08 & 0.00 & 1.00 & & & & & \\
\hline SOVRAT & -0.15 & 0.16 & 0.04 & -0.15 & -0.07 & 0.11 & 0.17 & 0.19 & 0.16 & -0.09 & -0.04 & 0.11 & 0.06 & -0.14 & -0.11 & -0.02 & 0.02 & -0.05 & 1.00 & & & & \\
\hline INTDB & 0.14 & -0.16 & 0.04 & 0.04 & 0.04 & -0.02 & 0.38 & 0.11 & -0.04 & 0.11 & 0.04 & 0.07 & 0.02 & -0.02 & 0.08 & 0.06 & 0.05 & 0.31 & 0.28 & 1.00 & & & \\
\hline CRBUR & -0.07 & 0.11 & 0.03 & -0.01 & 0.00 & 0.02 & 0.03 & 0.10 & 0.10 & 0.03 & 0.00 & 0.02 & 0.04 & -0.03 & -0.01 & -0.04 & 0.00 & 0.03 & 0.03 & 0.05 & 1.00 & & \\
\hline CREDR & -0.10 & 0.19 & 0.08 & -0.17 & -0.08 & 0.14 & 0.21 & 0.14 & -0.08 & 0.10 & 0.06 & 0.05 & 0.06 & -0.17 & -0.18 & -0.19 & -0.01 & -0.02 & 0.21 & 0.21 & -0.02 & 1.00 & \\
\hline ENFOR & -0.09 & 0.09 & 0.20 & -0.19 & -0.06 & 0.19 & -0.57 & -0.30 & -0.20 & 0.14 & 0.04 & -0.10 & -0.12 & 0.24 & 0.16 & 0.15 & 0.00 & -0.08 & 0.14 & -0.33 & -0.01 & 0.14 & 1.00 \\
\hline
\end{tabular}


Table 5: Bond ratings and analyst forecasts

This table presents regression estimates of credit ratings on analyst forecast variables and firm- and bond-level control variables. Table 1 provides the definitions and data sources for these variables. All models are estimated using OLS, corrected for clustering at the firm level and including both two-digit industry and year dummy variables (not reported). The sample period is 1991-2007. The associated t-statistics are reported in parentheses. $*{ }^{* *}$, and $* * *$ denote significance at the $10 \%, 5 \%$, and $1 \%$ levels, respectively.

\begin{tabular}{|c|c|c|c|c|c|c|}
\hline & Expected sign & (1) & $(2)$ & (3) & (4) & (5) \\
\hline \multicolumn{7}{|c|}{ Analyst forecast variables } \\
\hline ACCUR & + & $\begin{array}{c}21.569 * * * \\
(5.669)\end{array}$ & & & $\begin{array}{c}14.912 * * * \\
(3.653)\end{array}$ & \\
\hline DISP & - & & $\begin{array}{c}-50.955^{* * *} \\
(-6.116)\end{array}$ & & $\begin{array}{c}-30.771^{* * * *} \\
(-3.432)\end{array}$ & \\
\hline REV & - & & & $\begin{array}{c}-62.100 * * * \\
(-3.456)\end{array}$ & $\begin{array}{l}-12.463 \\
(-1.088)\end{array}$ & \\
\hline FACTOR & + & & & & & $\begin{array}{c}0.404 * * * \\
(6.639)\end{array}$ \\
\hline NUMEST & + & $\begin{array}{c}-0.008 \\
(-0.561)\end{array}$ & $\begin{array}{c}-0.006 \\
(-0.402)\end{array}$ & $\begin{array}{c}-0.007 \\
(-0.452)\end{array}$ & $\begin{array}{c}-0.009 \\
(-0.626)\end{array}$ & $\begin{array}{c}-0.010 \\
(-0.759)\end{array}$ \\
\hline \multicolumn{7}{|c|}{ Firm-level control variables } \\
\hline SIZE & + & $\begin{array}{c}1.049 * * * \\
(9.827)\end{array}$ & $\begin{array}{l}1.049 * * * \\
(10.185)\end{array}$ & $\begin{array}{l}1.090 * * * \\
(10.208)\end{array}$ & $\begin{array}{c}1.037 * * * \\
(9.818)\end{array}$ & $\begin{array}{c}1.056^{* * *} \\
(10.170)\end{array}$ \\
\hline LEV & - & $\begin{array}{c}-3.115^{* * *} \\
(-3.567)\end{array}$ & $\begin{array}{c}-2.612 * * * \\
(-2.986)\end{array}$ & $\begin{array}{c}-3.187 * * * \\
(-3.591)\end{array}$ & $\begin{array}{c}-2.640 * * * \\
(-3.071)\end{array}$ & $\begin{array}{c}-2.712 * * * \\
(-3.170)\end{array}$ \\
\hline PROFIT & + & $\begin{array}{c}7.513 * * * \\
(3.562)\end{array}$ & $\begin{array}{c}8.555^{* * * *} \\
(4.932)\end{array}$ & $\begin{array}{c}7.754 * * * \\
(3.831)\end{array}$ & $\begin{array}{c}8.176 * * * \\
(4.684)\end{array}$ & $\begin{array}{c}8.096 * * * \\
(4.584)\end{array}$ \\
\hline GROWTH & - or + & $\begin{array}{c}-0.174 \\
(-1.207)\end{array}$ & $\begin{array}{c}-0.217 \\
(-1.385)\end{array}$ & $\begin{array}{c}-0.219 \\
(-1.375)\end{array}$ & $\begin{array}{c}-0.175 \\
(-1.204)\end{array}$ & $\begin{array}{c}-0.193 \\
(-1.289)\end{array}$ \\
\hline USLIST & + & $\begin{array}{c}0.800 * * * \\
(2.936)\end{array}$ & $\begin{array}{c}0.692 * * * \\
(2.643)\end{array}$ & $\begin{array}{c}0.756 * * * \\
(2.828)\end{array}$ & $\begin{array}{c}0.721 * * * \\
(2.697)\end{array}$ & $\begin{array}{c}0.713^{* * *} \\
(2.694)\end{array}$ \\
\hline \multicolumn{7}{|c|}{ Bond-level control variables } \\
\hline PUB & + & $\begin{array}{c}0.858^{* * *} \\
(2.627)\end{array}$ & $\begin{array}{c}0.886 * * * \\
(2.768)\end{array}$ & $\begin{array}{c}0.873 * * * \\
(2.740)\end{array}$ & $\begin{array}{c}0.874 * * * \\
(2.721)\end{array}$ & $\begin{array}{c}0.878 * * * \\
(2.750)\end{array}$ \\
\hline AGE & - or + & $\begin{array}{c}0.021 \\
(0.178)\end{array}$ & $\begin{array}{c}0.018 \\
(0.157)\end{array}$ & $\begin{array}{c}0.047 \\
(0.401)\end{array}$ & $\begin{array}{c}-0.006 \\
(-0.053)\end{array}$ & $\begin{array}{c}0.001 \\
(0.005)\end{array}$ \\
\hline PROC & - or + & $\begin{array}{c}0.072 \\
(1.312)\end{array}$ & $\begin{array}{c}0.078 \\
(1.425)\end{array}$ & $\begin{array}{c}0.023 \\
(0.406)\end{array}$ & $\begin{array}{c}0.083 \\
(1.521)\end{array}$ & $\begin{array}{c}0.068 \\
(1.263)\end{array}$ \\
\hline CALL & - & $\begin{array}{c}-1.948^{* * *} \\
(-7.420)\end{array}$ & $\begin{array}{c}-1.891^{* * *} \\
(-7.434)\end{array}$ & $\begin{array}{c}-1.952 * * * \\
(-7.278)\end{array}$ & $\begin{array}{c}-1.881 * * * \\
(-7.357)\end{array}$ & $\begin{array}{c}-1.873 * * * \\
(-7.307)\end{array}$ \\
\hline CONV & - or + & $\begin{array}{c}-0.592 \\
(-0.669)\end{array}$ & $\begin{array}{c}-1.254 * * \\
(-2.079)\end{array}$ & $\begin{array}{c}-0.847 \\
(-1.006)\end{array}$ & $\begin{array}{l}-1.176^{*} \\
(-1.796)\end{array}$ & $\begin{array}{l}-1.287^{*} \\
(-1.926)\end{array}$ \\
\hline SYND & - or + & $\begin{array}{c}-0.522 * * * \\
(-3.688)\end{array}$ & $\begin{array}{c}-0.528 * * * \\
(-3.770)\end{array}$ & $\begin{array}{c}-0.386 * * * \\
(-2.623)\end{array}$ & $\begin{array}{c}-0.550 * * * \\
(-3.906)\end{array}$ & $\begin{array}{c}-0.502 * * * \\
(-3.555)\end{array}$ \\
\hline \multicolumn{7}{|c|}{ Institutional control variables } \\
\hline SOVRAT & + & $\begin{array}{c}0.227 * * * \\
(4.302)\end{array}$ & $\begin{array}{c}0.182 * * * \\
(3.268)\end{array}$ & $\begin{array}{c}0.193 * * * \\
(3.474)\end{array}$ & $\begin{array}{c}0.201 * * * \\
(3.718)\end{array}$ & $\begin{array}{c}0.195^{* * *} \\
(3.584)\end{array}$ \\
\hline INTDB & - & $\begin{array}{c}-2.792 * * * \\
(-4.053)\end{array}$ & $\begin{array}{c}-2.510^{* * *} \\
(-3.642)\end{array}$ & $\begin{array}{c}-2.529 * * * \\
(-3.475)\end{array}$ & $\begin{array}{c}-2.588 * * * \\
(-3.795)\end{array}$ & $\begin{array}{c}-2.496 * * * \\
(-3.610)\end{array}$ \\
\hline CRBUR & + & $\begin{array}{c}3.343 * * \\
(2.053)\end{array}$ & $\begin{array}{c}3.302 * * \\
(2.079)\end{array}$ & $\begin{array}{l}3.456 * \\
(1.927)\end{array}$ & $\begin{array}{c}3.199 * * \\
(2.070)\end{array}$ & $\begin{array}{c}3.224 * * \\
(2.016)\end{array}$ \\
\hline CREDR & + & $\begin{array}{c}0.167^{*} \\
(1.765)\end{array}$ & $\begin{array}{c}0.126 \\
(1.371)\end{array}$ & $\begin{array}{c}0.140 \\
(1.435)\end{array}$ & $\begin{array}{c}0.131 \\
(1.418)\end{array}$ & $\begin{array}{c}0.125 \\
(1.335)\end{array}$ \\
\hline ENFOR & + & $\begin{array}{c}0.006 \\
(0.940)\end{array}$ & $\begin{array}{c}0.009 \\
(1.258)\end{array}$ & $\begin{array}{c}0.015^{* *} \\
(2.055)\end{array}$ & $\begin{array}{c}0.006 \\
(0.846)\end{array}$ & $\begin{array}{c}0.008 \\
(1.110)\end{array}$ \\
\hline Constant & ? & $\begin{array}{c}-0.637 \\
(-0.300)\end{array}$ & $\begin{array}{c}-0.175 \\
(-0.082)\end{array}$ & $\begin{array}{c}-1.287 \\
(-0.577)\end{array}$ & $\begin{array}{c}0.221 \\
(0.105)\end{array}$ & $\begin{array}{c}-0.467 \\
(-0.222)\end{array}$ \\
\hline \# of observations & & 2,523 & 2,543 & 2,543 & 2,521 & 2,521 \\
\hline Adj. R-squared & & 0.570 & 0.580 & 0.562 & 0.582 & 0.581 \\
\hline
\end{tabular}

\section{Table 6: Credit spreads and analyst forecasts}

This table presents regression estimates of credit spreads on analyst forecast variables, rating residuals calculated from the ratings regression, and firm- and bond-level control variables. Table 1 provides the definitions and data sources for these 
variables. All models are estimated using OLS, corrected for clustering at the firm level and including both two-digit industry and year dummy variables (not reported). The sample period is 1991-2007. The associated t-statistics are reported in parentheses. *, **, and *** denote significance at the $10 \%, 5 \%$, and $1 \%$ levels, respectively.

\begin{tabular}{|c|c|c|c|c|c|c|}
\hline & Expected sign & (1) & $(2)$ & (3) & (4) & (5) \\
\hline \multicolumn{7}{|c|}{ Analyst forecast variables } \\
\hline ACCUR & - & $\begin{array}{c}-6.973 * * * \\
(-3.763)\end{array}$ & & & $\begin{array}{c}-4.708 * * \\
(-2.261)\end{array}$ & \\
\hline DISP & + & & $\begin{array}{c}15.230 * * * \\
(5.002)\end{array}$ & & $\begin{array}{c}10.093 * * * \\
(2.624)\end{array}$ & \\
\hline REV & + & & & $\begin{array}{c}15.931^{* * *} \\
(2.700)\end{array}$ & $\begin{array}{c}2.281 \\
(0.372)\end{array}$ & \\
\hline FACTOR & - & & & & & $\begin{array}{c}-0.124 * * * \\
(-4.940)\end{array}$ \\
\hline NUMEST & - & $\begin{array}{l}-0.010 * \\
(-1.808)\end{array}$ & $\begin{array}{c}-0.010^{* *} \\
(-1.965)\end{array}$ & $\begin{array}{c}-0.009 \\
(-1.638)\end{array}$ & $\begin{array}{l}-0.010^{*} \\
(-1.799)\end{array}$ & $\begin{array}{l}-0.009 * \\
(-1.679)\end{array}$ \\
\hline \multicolumn{7}{|c|}{ Firm-level control variables } \\
\hline SIZE & - & $\begin{array}{c}-0.278^{* * *} \\
(-6.514)\end{array}$ & $\begin{array}{c}-0.277 * * * \\
(-6.463)\end{array}$ & $\begin{array}{c}-0.295^{* * *} \\
(-6.922)\end{array}$ & $\begin{array}{c}-0.272 * * * \\
(-6.259)\end{array}$ & $\begin{array}{c}-0.278 * * * \\
(-6.560)\end{array}$ \\
\hline LEV & + & $\begin{array}{c}0.563 \\
(1.630)\end{array}$ & $\begin{array}{c}0.479 \\
(1.370)\end{array}$ & $\begin{array}{l}0.624 * \\
(1.804)\end{array}$ & $\begin{array}{c}0.461 \\
(1.330)\end{array}$ & $\begin{array}{c}0.489 \\
(1.430)\end{array}$ \\
\hline PROFIT & - & $\begin{array}{c}-3.186 * * * \\
(-4.001)\end{array}$ & $\begin{array}{c}-3.100 * * * \\
(-3.722)\end{array}$ & $\begin{array}{c}-3.262 * * * \\
(-3.810)\end{array}$ & $\begin{array}{c}-2.909 * * * \\
(-3.530)\end{array}$ & $\begin{array}{c}-2.880 * * * \\
(-3.520)\end{array}$ \\
\hline GROWTH & - or + & $\begin{array}{c}0.285^{* * *} \\
(2.831)\end{array}$ & $\begin{array}{c}0.309 * * * \\
(2.881)\end{array}$ & $\begin{array}{c}0.309 * * * \\
(2.919)\end{array}$ & $\begin{array}{c}0.295^{* * *} \\
(2.851)\end{array}$ & $\begin{array}{c}0.302^{* * *} \\
(2.861)\end{array}$ \\
\hline USLIST & - & $\begin{array}{c}-0.323 * * * \\
(-3.953)\end{array}$ & $\begin{array}{c}-0.308^{* * *} \\
(-3.745)\end{array}$ & $\begin{array}{c}-0.317 * * * \\
(-3.847)\end{array}$ & $\begin{array}{c}-0.308 * * * \\
(-3.755)\end{array}$ & $\begin{array}{c}-0.305^{* * *} \\
(-3.736)\end{array}$ \\
\hline \multicolumn{7}{|c|}{ Bond-level control variables } \\
\hline PUB & - & $\begin{array}{c}-0.518 * * * \\
(-4.537)\end{array}$ & $\begin{array}{c}-0.523 * * * \\
(-4.798)\end{array}$ & $\begin{array}{c}-0.527 * * * \\
(-4.679)\end{array}$ & $\begin{array}{c}-0.516 * * * \\
(-4.676)\end{array}$ & $\begin{array}{c}-0.517 * * * \\
(-4.715)\end{array}$ \\
\hline AGE & - or + & $\begin{array}{c}0.074 \\
(1.252)\end{array}$ & $\begin{array}{c}0.077 \\
(1.330)\end{array}$ & $\begin{array}{c}0.066 \\
(1.135)\end{array}$ & $\begin{array}{c}0.083 \\
(1.407)\end{array}$ & $\begin{array}{c}0.080 \\
(1.377)\end{array}$ \\
\hline PROC & - or + & $\begin{array}{c}-0.027 \\
(-1.218)\end{array}$ & $\begin{array}{c}-0.029 \\
(-1.330)\end{array}$ & $\begin{array}{c}-0.015 \\
(-0.691)\end{array}$ & $\begin{array}{c}-0.032 \\
(-1.403)\end{array}$ & $\begin{array}{c}-0.026 \\
(-1.213)\end{array}$ \\
\hline CALL & + & $\begin{array}{l}1.011^{* * *} \\
(11.489)\end{array}$ & $\begin{array}{c}0.993 * * * \\
(11.377)\end{array}$ & $\begin{array}{c}1.007 * * * \\
(11.179)\end{array}$ & $\begin{array}{c}0.991^{* * *} \\
(11.445)\end{array}$ & $\begin{array}{c}0.988 * * * \\
(11.478)\end{array}$ \\
\hline CONV & - or + & $\begin{array}{c}0.364 \\
(0.321)\end{array}$ & $\begin{array}{c}0.373 \\
(0.329)\end{array}$ & $\begin{array}{c}0.479 \\
(0.417)\end{array}$ & $\begin{array}{c}0.321 \\
(0.284)\end{array}$ & $\begin{array}{c}0.361 \\
(0.319)\end{array}$ \\
\hline SYND & - or + & $\begin{array}{c}0.055 \\
(0.737)\end{array}$ & $\begin{array}{c}0.056 \\
(0.745)\end{array}$ & $\begin{array}{c}0.018 \\
(0.241)\end{array}$ & $\begin{array}{c}0.061 \\
(0.805)\end{array}$ & $\begin{array}{c}0.043 \\
(0.583)\end{array}$ \\
\hline RATR & - & $\begin{array}{c}-0.212 * * * \\
(-11.718)\end{array}$ & $\begin{array}{c}-0.214 * * * \\
(-11.680)\end{array}$ & $\begin{array}{c}-0.217^{* * *} \\
(-11.745)\end{array}$ & $\begin{array}{c}-0.213^{* * *} \\
(-11.791)\end{array}$ & $\begin{array}{c}-0.215^{* * *} \\
(-11.710)\end{array}$ \\
\hline Institutional control & & & & & & \\
\hline SOVRAT & - & $\begin{array}{c}-0.129 * * * \\
(-5.479)\end{array}$ & $\begin{array}{c}-0.116^{* * *} \\
(-5.364)\end{array}$ & $\begin{array}{c}-0.121 * * * \\
(-5.281)\end{array}$ & $\begin{array}{c}-0.120 * * * \\
(-5.477)\end{array}$ & $\begin{array}{c}-0.118 * * * \\
(-5.335)\end{array}$ \\
\hline INTDB & + & $\begin{array}{c}1.608 * * * \\
(5.683)\end{array}$ & $\begin{array}{c}1.515^{* * *} \\
(5.311)\end{array}$ & $\begin{array}{c}1.514 * * * \\
(5.365)\end{array}$ & $\begin{array}{c}1.551^{* * *} \\
(5.395)\end{array}$ & $\begin{array}{c}1.520^{* * *} \\
(5.366)\end{array}$ \\
\hline CRBUR & - & $\begin{array}{c}-1.030 * * * \\
(-4.591)\end{array}$ & $\begin{array}{c}-1.060 * * * \\
(-4.903)\end{array}$ & $\begin{array}{c}-1.066^{* * *} \\
(-4.842)\end{array}$ & $\begin{array}{c}-1.034 * * * \\
(-4.644)\end{array}$ & $\begin{array}{c}-1.042^{* * *} \\
(-4.800)\end{array}$ \\
\hline CREDR & - & $\begin{array}{c}-0.002 \\
(-0.066)\end{array}$ & $\begin{array}{c}0.009 \\
(0.299)\end{array}$ & $\begin{array}{c}0.006 \\
(0.207)\end{array}$ & $\begin{array}{c}0.004 \\
(0.128)\end{array}$ & $\begin{array}{c}0.006 \\
(0.193)\end{array}$ \\
\hline ENFOR & - & $\begin{array}{c}-0.007 * * * \\
(-2.748)\end{array}$ & $\begin{array}{c}-0.007 * * * \\
(-3.186)\end{array}$ & $\begin{array}{c}-0.009 * * * \\
(-3.763)\end{array}$ & $\begin{array}{c}-0.006^{* * *} \\
(-2.733)\end{array}$ & $\begin{array}{c}-0.007 * * * \\
(-3.046)\end{array}$ \\
\hline Constant & ? & $\begin{array}{c}7.781^{* * *} \\
(13.450)\end{array}$ & $\begin{array}{c}7.657 * * * \\
(14.689)\end{array}$ & $\begin{array}{c}8.043^{* * *} \\
(14.811)\end{array}$ & $\begin{array}{c}7.491^{* * *} \\
(13.822)\end{array}$ & $\begin{array}{c}7.715^{* * *} \\
(14.521)\end{array}$ \\
\hline \# of observations & & 2,521 & 2,521 & 2,521 & 2,521 & 2,521 \\
\hline Adjusted R-squared & & 0.494 & 0.495 & 0.489 & 0.498 & 0.497 \\
\hline
\end{tabular}




\section{Table 7: Robustness checks}

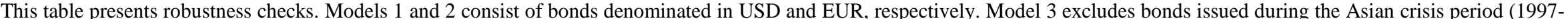

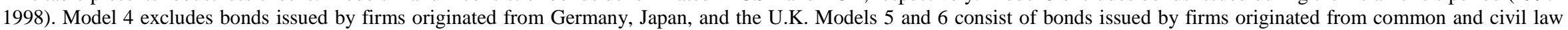

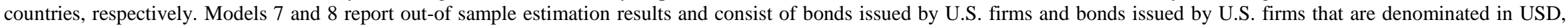

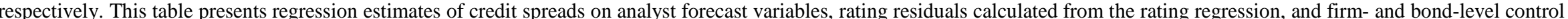

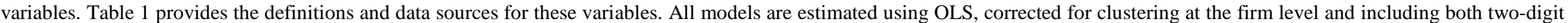

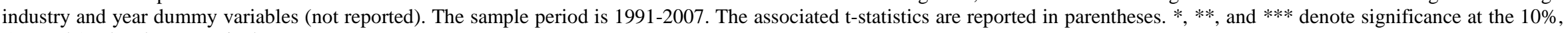
$5 \%$, and $1 \%$ levels, respectively.

\begin{tabular}{|c|c|c|c|c|c|c|c|c|}
\hline & (1) & $(2)$ & (3) & (4) & (5) & (6) & 7) & (8) \\
\hline Subsample & Bonds in USD & $\begin{array}{l}\text { Bonds in } \\
\text { EUR }\end{array}$ & $\begin{array}{l}\text { Ex. Asian crisis } \\
\text { period }\end{array}$ & $\begin{array}{c}\text { Ex. Germany, } \\
\text { Japan, and } \\
\text { U.K. }\end{array}$ & Common law & Civil law & U.S. bonds & $\begin{array}{l}\text { U.S. bonds } \\
\text { in USD }\end{array}$ \\
\hline \multicolumn{9}{|l|}{ Analyst forecast variables } \\
\hline FACTOR & $\begin{array}{c}-0.207 * * * \\
(-7.047)\end{array}$ & $\begin{array}{c}-0.113 * * \\
(-2.456)\end{array}$ & $\begin{array}{c}-0.149 * * * \\
(-5.935)\end{array}$ & $\begin{array}{c}-0.199 * * * \\
(-6.808)\end{array}$ & $\begin{array}{c}-0.125^{* * *} \\
(-4.176)\end{array}$ & $\begin{array}{c}-0.132 * * * \\
(-3.019)\end{array}$ & $\begin{array}{c}-0.187 * * * \\
(-9.910)\end{array}$ & $\begin{array}{c}-0.193 * * * \\
(-10.413)\end{array}$ \\
\hline NUMEST & $\begin{array}{c}-0.016^{*} \\
(-1.852)\end{array}$ & $\begin{array}{c}0.008 \\
(1.555)\end{array}$ & $\begin{array}{c}-0.007 \\
(-1.165)\end{array}$ & $\begin{array}{l}0.015^{*} \\
(1.810)\end{array}$ & $\begin{array}{c}-0.022 * * \\
(-2.562)\end{array}$ & $\begin{array}{l}0.015^{*} \\
(1.677)\end{array}$ & $\begin{array}{c}-0.004 \\
(-0.734)\end{array}$ & $\begin{array}{c}-0.002 \\
(-0.358)\end{array}$ \\
\hline \multicolumn{9}{|l|}{ Firm-level control variables } \\
\hline SIZE & $\begin{array}{c}-0.246 * * * \\
(-4.125)\end{array}$ & $\begin{array}{c}-0.351 * * * \\
(-4.922)\end{array}$ & $\begin{array}{c}-0.284 * * * \\
(-6.152)\end{array}$ & $\begin{array}{c}-0.450 * * * \\
(-6.956)\end{array}$ & $\begin{array}{c}-0.227 * * * \\
(-4.752)\end{array}$ & $\begin{array}{c}-0.391 * * * \\
(-4.442)\end{array}$ & $\begin{array}{c}-0.234 * * * \\
(-4.937)\end{array}$ & $\begin{array}{c}-0.257 * * * \\
(-5.142)\end{array}$ \\
\hline LEV & $\begin{array}{c}0.440 \\
(0.930)\end{array}$ & $\begin{array}{c}-0.492 \\
(-0.899)\end{array}$ & $\begin{array}{c}0.483 \\
(1.306)\end{array}$ & $\begin{array}{c}0.915^{* *} \\
(2.203)\end{array}$ & $\begin{array}{c}0.269 \\
(0.731)\end{array}$ & $\begin{array}{c}0.608 \\
(0.711)\end{array}$ & $\begin{array}{c}0.466 * * * \\
(3.523)\end{array}$ & $\begin{array}{c}0.534 * * * \\
(4.187)\end{array}$ \\
\hline PROFIT & $\begin{array}{c}-3.886 * * * \\
(-3.719)\end{array}$ & $\begin{array}{c}-4.048 * * * \\
(-2.705)\end{array}$ & $\begin{array}{c}-2.815^{* * *} \\
(-3.328)\end{array}$ & $\begin{array}{c}-4.929 * * * \\
(-3.766)\end{array}$ & $\begin{array}{c}-1.812 * * \\
(-2.421)\end{array}$ & $\begin{array}{c}-7.196 * * * \\
(-2.644)\end{array}$ & $\begin{array}{c}-3.441^{* * *} \\
(-11.913)\end{array}$ & $\begin{array}{c}-3.372^{* * *} \\
(-11.910)\end{array}$ \\
\hline GROWTH & $\begin{array}{l}0.346^{*} \\
(1.722)\end{array}$ & $\begin{array}{l}0.144^{*} \\
(1.827)\end{array}$ & $\begin{array}{c}0.327 * * * \\
(2.938)\end{array}$ & $\begin{array}{l}0.212 * \\
(1.659)\end{array}$ & $\begin{array}{c}0.389 * * * \\
(4.102)\end{array}$ & $\begin{array}{c}0.213 \\
(1.301)\end{array}$ & $\begin{array}{c}0.116^{* * *} \\
(4.298)\end{array}$ & $\begin{array}{c}0.107 * * * \\
(4.233)\end{array}$ \\
\hline USLIST & $\begin{array}{c}-0.427 * * * \\
(-4.432)\end{array}$ & $\begin{array}{c}-0.156 \\
(-1.030)\end{array}$ & $\begin{array}{c}-0.265 * * * \\
(-2.986)\end{array}$ & $\begin{array}{c}-0.319 * * * \\
(-3.336)\end{array}$ & $\begin{array}{c}-0.409 * * * \\
(-4.438)\end{array}$ & $\begin{array}{l}-0.300^{*} \\
(-1.736)\end{array}$ & & \\
\hline \multicolumn{9}{|l|}{ Bond-level control variables } \\
\hline PUB & $\begin{array}{c}-0.329 * * * \\
(-2.846)\end{array}$ & $\begin{array}{c}-0.403 \\
(-0.609)\end{array}$ & $\begin{array}{c}-0.479 * * * \\
(-3.865)\end{array}$ & $\begin{array}{c}-0.399 * * * \\
(-3.041)\end{array}$ & $\begin{array}{c}-0.437 * * * \\
(-3.763)\end{array}$ & $\begin{array}{c}-0.645^{* * *} \\
(-3.226)\end{array}$ & $\begin{array}{c}-1.016 * * * \\
(-19.314)\end{array}$ & $\begin{array}{c}-1.016^{* * *} \\
(-19.538)\end{array}$ \\
\hline AGE & $\begin{array}{c}-0.047 \\
(-0.674)\end{array}$ & $\begin{array}{c}0.220 * * * \\
(2.617)\end{array}$ & $\begin{array}{c}0.072 \\
(1.151)\end{array}$ & $\begin{array}{c}0.076 \\
(1.025)\end{array}$ & $\begin{array}{c}0.081 \\
(1.568)\end{array}$ & $\begin{array}{c}0.066 \\
(0.605)\end{array}$ & $\begin{array}{l}-0.043^{*} \\
(-1.918)\end{array}$ & $\begin{array}{c}-0.046^{* *} \\
(-2.448)\end{array}$ \\
\hline PROC & $\begin{array}{c}-0.014 \\
(-0.461)\end{array}$ & $\begin{array}{c}-0.079 \\
(-1.292)\end{array}$ & $\begin{array}{c}-0.036 \\
(-1.629)\end{array}$ & $\begin{array}{c}-0.040 \\
(-0.983)\end{array}$ & $\begin{array}{c}-0.044 \\
(-0.913)\end{array}$ & $\begin{array}{c}-0.008 \\
(-0.230)\end{array}$ & $\begin{array}{c}0.077 * * * \\
(4.663)\end{array}$ & $\begin{array}{c}0.071^{* * *} \\
(4.165)\end{array}$ \\
\hline CALL & $\begin{array}{c}0.902 * * * \\
(8.027)\end{array}$ & $\begin{array}{c}1.660^{* * *} \\
(4.458)\end{array}$ & $\begin{array}{l}1.014^{* * *} \\
(11.226)\end{array}$ & $\begin{array}{c}0.990 * * * \\
(6.689)\end{array}$ & $\begin{array}{c}0.993 * * * \\
(8.821)\end{array}$ & $\begin{array}{c}1.066^{* * *} \\
(5.094)\end{array}$ & $\begin{array}{c}0.512 * * * \\
(14.836)\end{array}$ & $\begin{array}{c}0.533 * * * \\
(16.174)\end{array}$ \\
\hline CONV & $\begin{array}{c}-2.198 * * * \\
(-7.132)\end{array}$ & $\begin{array}{c}1.482 \\
(1.098)\end{array}$ & $\begin{array}{c}-0.467 \\
(-0.512)\end{array}$ & $\begin{array}{c}-0.678 \\
(-0.652)\end{array}$ & $\begin{array}{c}-2.298 * * * \\
(-11.246)\end{array}$ & $\begin{array}{c}0.343 \\
(0.259)\end{array}$ & $\begin{array}{c}2.538 \\
(1.580)\end{array}$ & $\begin{array}{c}2.529 \\
(1.576)\end{array}$ \\
\hline SYND & $\begin{array}{c}-0.094 \\
(-1.011)\end{array}$ & $\begin{array}{c}0.081 \\
(0.501)\end{array}$ & $\begin{array}{c}0.033 \\
(0.426)\end{array}$ & $\begin{array}{c}0.008 \\
(0.075)\end{array}$ & $\begin{array}{c}0.054 \\
(0.699)\end{array}$ & $\begin{array}{c}0.090 \\
(0.626)\end{array}$ & $\begin{array}{l}-0.076^{*} \\
(-1.748)\end{array}$ & $\begin{array}{c}-0.069 \\
(-1.588)\end{array}$ \\
\hline RATR & $\begin{array}{c}-0.283 * * * \\
(-12.219)\end{array}$ & $\begin{array}{c}-0.226 * * * \\
(-7.041)\end{array}$ & $\begin{array}{c}-0.224 * * * \\
(-11.430)\end{array}$ & $\begin{array}{c}-0.288 * * * \\
(-10.358)\end{array}$ & $\begin{array}{c}-0.250 * * * \\
(-11.545)\end{array}$ & $\begin{array}{c}-0.203^{* * *} \\
(-5.525)\end{array}$ & $\begin{array}{c}-0.223^{* * *} \\
(-13.229)\end{array}$ & $\begin{array}{c}-0.226 * * * \\
(-14.594)\end{array}$ \\
\hline
\end{tabular}


Institutional control variables

SOVRAT

CRBUR

CREDR

ENFOR

Constant

\# of observations

Adjusted R-squared

\begin{tabular}{|c|c|c|c|c|c|c|c|}
\hline $\begin{array}{c}-0.158 * * * \\
(-5.925)\end{array}$ & $\begin{array}{c}-0.039 \\
(-0.938)\end{array}$ & $\begin{array}{c}-0.126 * * * \\
(-5.401)\end{array}$ & $\begin{array}{c}-0.162 * * * \\
(-7.225)\end{array}$ & $\begin{array}{c}-0.100 * * * \\
(-2.647)\end{array}$ & $\begin{array}{c}-0.151 * * * \\
(-5.613)\end{array}$ & & \\
\hline $1.503^{* * *}$ & 0.603 & $1.513^{* * *}$ & $1.250 * *$ & $1.751^{* * *}$ & $1.291^{* * *}$ & & \\
\hline (4.228) & (1.462) & (4.978) & $(2.550)$ & (4.866) & $(2.676)$ & & \\
\hline$-0.812 * * *$ & & $-0.955 * * *$ & $-0.893 * * *$ & $-1.119 * * *$ & $-1.432 * * *$ & & \\
\hline$(-3.001)$ & & $(-3.738)$ & $(-3.912)$ & $(-3.625)$ & $(-3.005)$ & & \\
\hline 0.030 & -0.029 & 0.003 & -0.067 & 0.029 & -0.007 & & \\
\hline$(0.646)$ & $(-0.582)$ & (0.078) & $(-1.216)$ & $(0.671)$ & $(-0.128)$ & & \\
\hline-0.002 & -0.003 & $-0.007 * * *$ & -0.003 & -0.008 & -0.007 & & \\
\hline$(-0.640)$ & $(-0.919)$ & $(-2.877)$ & $(-1.057)$ & $(-1.476)$ & $(-1.338)$ & & \\
\hline 7.973*** & $6.012 * * *$ & $7.841^{* * *}$ & $8.675^{* * *}$ & 7.117*** & $9.121 * * *$ & $3.588 * * *$ & $3.754 * * *$ \\
\hline (13.330) & (3.998) & $(13.886)$ & (14.847) & (11.055) & (12.109) & (9.717) & (9.702) \\
\hline 1,184 & 454 & 2,248 & 994 & 1,320 & 1,201 & 10,036 & 9,354 \\
\hline 0.648 & 0.593 & 0.502 & 0.572 & 0.658 & 0.360 & 0.608 & 0.632 \\
\hline
\end{tabular}


Table 8: Credit spreads, financial analysts, and institutional environment

This table presents regression estimates of credit spreads on the analyst forecast factor, rating residuals calculated from the ratings regression, and firm-, bond-, and institutionallevel control variables for companies originating in countries with weak versus strong institutions. Table 1 provides the definitions and data sources for these variables. All models are estimated using OLS, corrected for clustering at the firm level and including two-digit industry, year, and country dummy variables (not reported). The sample period is 19912007. The associated t-statistics are reported in parentheses. *, **, and *** denote significance at the $10 \%, 5 \%$, and $1 \%$ levels, respectively.

\begin{tabular}{|c|c|c|c|c|c|c|c|c|c|c|}
\hline & \multicolumn{2}{|c|}{ Creditor rights } & \multicolumn{2}{|c|}{ Press freedom } & \multicolumn{2}{|c|}{ Rule of law } & \multicolumn{2}{|c|}{ Repudiation risk } & \multicolumn{2}{|c|}{ Expropriation risk } \\
\hline & Low & High & Low & High & Weak & Strong & High & Low & High & Low \\
\hline & (1) & $(2)$ & (3) & (4) & (5) & (6) & $(7)$ & (8) & (9) & (10) \\
\hline \multicolumn{11}{|c|}{ Analyst forecast variables } \\
\hline FACTOR & $\begin{array}{c}-0.227 * * * \\
(-6.099)\end{array}$ & $\begin{array}{c}-0.069 * * \\
(-2.322)\end{array}$ & $\begin{array}{c}-0.194 * * * \\
(-5.302)\end{array}$ & $\begin{array}{c}-0.086 * * * \\
(-2.699)\end{array}$ & $\begin{array}{c}-0.209 * * * \\
(-5.211)\end{array}$ & $\begin{array}{c}-0.112 * * * \\
(-3.616)\end{array}$ & $\begin{array}{c}-0.191 * * * \\
(-6.998)\end{array}$ & $\begin{array}{c}-0.057 \\
(-1.609)\end{array}$ & $\begin{array}{c}-0.244 * * * \\
(-5.343)\end{array}$ & $\begin{array}{c}-0.116 * * * \\
(-4.037)\end{array}$ \\
\hline NUMEST & $\begin{array}{c}0.022 * * \\
(2.594)\end{array}$ & $\begin{array}{c}-0.018 * * \\
(-2.033)\end{array}$ & $\begin{array}{c}-0.008 \\
(-0.691)\end{array}$ & $\begin{array}{c}0.002 \\
(0.262)\end{array}$ & $\begin{array}{c}0.015 \\
(1.347)\end{array}$ & $\begin{array}{c}-0.010 \\
(-1.092)\end{array}$ & $\begin{array}{c}0.022^{* * * *} \\
(3.394)\end{array}$ & $\begin{array}{l}-0.019 * \\
(-1.867)\end{array}$ & $\begin{array}{c}0.043 * * * \\
(3.789)\end{array}$ & $\begin{array}{l}-0.014^{*} \\
(-1.687)\end{array}$ \\
\hline \multicolumn{11}{|c|}{ Firm-level control variables } \\
\hline SIZE & $\begin{array}{c}-0.557 * * * \\
(-7.651)\end{array}$ & $\begin{array}{c}-0.234 * * * \\
(-4.062)\end{array}$ & $\begin{array}{c}-0.326 * * * \\
(-5.234)\end{array}$ & $\begin{array}{c}-0.299 * * * \\
(-3.213)\end{array}$ & $\begin{array}{c}-0.364 * * * \\
(-4.970)\end{array}$ & $\begin{array}{c}-0.321 * * * \\
(-5.098)\end{array}$ & $\begin{array}{c}-0.593 * * * \\
(-9.855)\end{array}$ & $\begin{array}{c}-0.213^{* * *} \\
(-3.201)\end{array}$ & $\begin{array}{c}-0.699 * * * \\
(-7.564)\end{array}$ & $\begin{array}{c}-0.278 * * * \\
(-4.860)\end{array}$ \\
\hline LEV & $\begin{array}{l}1.074 * * \\
(2.291)\end{array}$ & $\begin{array}{c}0.259 \\
(0.589)\end{array}$ & $\begin{array}{c}0.929 * * \\
(2.395)\end{array}$ & $\begin{array}{c}0.295 \\
(0.606)\end{array}$ & $\begin{array}{c}0.562 \\
(0.979)\end{array}$ & $\begin{array}{c}0.402 \\
(0.803)\end{array}$ & $\begin{array}{c}1.737 * * * \\
(4.240)\end{array}$ & $\begin{array}{c}0.207 \\
(0.410)\end{array}$ & $\begin{array}{l}1.338 \\
(1.613)\end{array}$ & $\begin{array}{c}0.269 \\
(0.670)\end{array}$ \\
\hline PROFIT & $\begin{array}{c}-4.179 * * * \\
(-3.750)\end{array}$ & $\begin{array}{c}-1.130 \\
(-1.234)\end{array}$ & $\begin{array}{c}-2.446 * * * \\
(-3.135)\end{array}$ & $\begin{array}{c}-4.262 * * * \\
(-2.874)\end{array}$ & $\begin{array}{c}-2.543 * * * \\
(-2.616)\end{array}$ & $\begin{array}{c}-2.953^{* *} \\
(-2.180)\end{array}$ & $\begin{array}{c}-3.878 * * * \\
(-4.407)\end{array}$ & $\begin{array}{c}-0.809 \\
(-0.860)\end{array}$ & $\begin{array}{c}-5.224 * * * \\
(-3.304)\end{array}$ & $\begin{array}{c}-2.271^{* *} \\
(-2.548)\end{array}$ \\
\hline GROWTH & $\begin{array}{c}-0.109 \\
(-1.250)\end{array}$ & $\begin{array}{c}0.470 * * * \\
(3.458)\end{array}$ & $\begin{array}{c}0.442 * * * \\
(3.591)\end{array}$ & $\begin{array}{c}0.142 \\
(1.293)\end{array}$ & $\begin{array}{c}0.302 * * * \\
(2.620)\end{array}$ & $\begin{array}{c}0.285 \\
(1.450)\end{array}$ & $\begin{array}{c}0.072 \\
(0.885)\end{array}$ & $\begin{array}{c}0.707 * * * \\
(4.445)\end{array}$ & $\begin{array}{l}0.223^{*} \\
(1.703)\end{array}$ & $\begin{array}{c}0.362 * * * \\
(2.684)\end{array}$ \\
\hline USLIST & $\begin{array}{c}-0.289 * * \\
(-2.423)\end{array}$ & $\begin{array}{c}-0.360 * * * \\
(-2.902)\end{array}$ & $\begin{array}{c}-0.504 * * * \\
(-4.009)\end{array}$ & $\begin{array}{l}-0.261^{*} \\
(-1.916)\end{array}$ & $\begin{array}{l}-0.249^{*} \\
(-1.897)\end{array}$ & $\begin{array}{c}-0.499 * * * \\
(-3.738)\end{array}$ & $\begin{array}{c}-0.313^{* * *} \\
(-3.271)\end{array}$ & $\begin{array}{c}-0.426 * * \\
(-2.552)\end{array}$ & $\begin{array}{c}-0.567 * * * \\
(-3.768)\end{array}$ & $\begin{array}{c}-0.404 * * * \\
(-3.404)\end{array}$ \\
\hline \multicolumn{11}{|c|}{ Bond-level control variables } \\
\hline PUB & $\begin{array}{c}-0.254 \\
(-1.522)\end{array}$ & $\begin{array}{c}-0.453 * * * \\
(-3.477)\end{array}$ & $\begin{array}{l}-0.239 * \\
(-1.652)\end{array}$ & $\begin{array}{c}-0.917 * * * \\
(-4.935)\end{array}$ & $\begin{array}{c}-0.831 * * * \\
(-3.545)\end{array}$ & $\begin{array}{c}-0.456 * * * \\
(-3.480)\end{array}$ & $\begin{array}{c}-0.484 * * * \\
(-3.449)\end{array}$ & $\begin{array}{c}-0.490 * * * \\
(-2.609)\end{array}$ & $\begin{array}{c}-0.765 * * * \\
(-3.917)\end{array}$ & $\begin{array}{c}-0.546 * * * \\
(-3.866)\end{array}$ \\
\hline AGE & $\begin{array}{c}0.178^{* *} \\
(2.005)\end{array}$ & $\begin{array}{c}0.083 \\
(1.157)\end{array}$ & $\begin{array}{c}0.096 \\
(1.106)\end{array}$ & $\begin{array}{c}0.136 * * \\
(2.193)\end{array}$ & $\begin{array}{c}0.239 * * * \\
(3.374)\end{array}$ & $\begin{array}{c}0.038 \\
(0.519)\end{array}$ & $\begin{array}{l}0.159 * \\
(1.947)\end{array}$ & $\begin{array}{c}0.093 \\
(1.177)\end{array}$ & $\begin{array}{c}0.184 \\
(1.134)\end{array}$ & $\begin{array}{c}0.089 \\
(1.376)\end{array}$ \\
\hline PROC & $\begin{array}{c}0.025 \\
(0.428)\end{array}$ & $\begin{array}{c}-0.030 \\
(-1.164)\end{array}$ & $\begin{array}{c}0.012 \\
(0.414)\end{array}$ & $\begin{array}{c}-0.021 \\
(-0.614)\end{array}$ & $\begin{array}{c}-0.231^{* *} \\
(-2.470)\end{array}$ & $\begin{array}{c}0.022 \\
(0.877)\end{array}$ & $\begin{array}{c}-0.026 \\
(-0.591)\end{array}$ & $\begin{array}{c}0.005 \\
(0.176)\end{array}$ & $\begin{array}{c}-0.166 * * \\
(-2.305)\end{array}$ & $\begin{array}{c}0.002 \\
(0.082)\end{array}$ \\
\hline CALL & $\begin{array}{c}0.923 * * * \\
(6.288)\end{array}$ & $\begin{array}{c}1.161^{* * *} \\
(7.646)\end{array}$ & $\begin{array}{c}0.919 * * * \\
(8.278)\end{array}$ & $\begin{array}{c}0.990 * * * \\
(4.833)\end{array}$ & $\begin{array}{c}0.863 * * * \\
(4.966)\end{array}$ & $\begin{array}{c}1.140^{* * *} \\
(8.584)\end{array}$ & $\begin{array}{c}0.937 * * * \\
(7.068)\end{array}$ & $\begin{array}{c}0.995 * * * \\
(6.568)\end{array}$ & $\begin{array}{c}1.137 * * * \\
(5.148)\end{array}$ & $\begin{array}{c}0.925^{* * *} \\
(8.795)\end{array}$ \\
\hline CONV & $\begin{array}{l}1.949^{*} \\
(1.718)\end{array}$ & $\begin{array}{c}-0.513 \\
(-0.362)\end{array}$ & $\begin{array}{c}-0.187 \\
(-0.099)\end{array}$ & $\begin{array}{l}1.606 \\
(1.537)\end{array}$ & $\begin{array}{c}-1.815^{* * *} \\
(-3.948)\end{array}$ & $\begin{array}{c}1.334 \\
(0.918)\end{array}$ & $\begin{array}{c}0.939 \\
(0.780)\end{array}$ & $\begin{array}{c}-0.201 \\
(-0.112)\end{array}$ & $\begin{array}{c}-1.609 * * \\
(-2.179)\end{array}$ & $\begin{array}{c}0.984 \\
(0.745)\end{array}$ \\
\hline SYND & $\begin{array}{c}-0.105 \\
(-0.788)\end{array}$ & $\begin{array}{c}0.144 \\
(1.363)\end{array}$ & $\begin{array}{c}-0.022 \\
(-0.183)\end{array}$ & $\begin{array}{c}0.123 \\
(1.311)\end{array}$ & $\begin{array}{c}0.271 \\
(1.646)\end{array}$ & $\begin{array}{l}0.163^{*} \\
(1.675)\end{array}$ & $\begin{array}{c}0.051 \\
(0.416)\end{array}$ & $\begin{array}{c}0.096 \\
(0.876)\end{array}$ & $\begin{array}{c}0.526 * * * \\
(2.718)\end{array}$ & $\begin{array}{c}0.090 \\
(0.987)\end{array}$ \\
\hline RATR & $\begin{array}{c}-0.280 * * * \\
(-10.632)\end{array}$ & $\begin{array}{c}-0.199 * * * \\
(-8.545)\end{array}$ & $\begin{array}{c}-0.258 * * * \\
(-9.649)\end{array}$ & $\begin{array}{c}-0.186 * * * \\
(-7.011)\end{array}$ & $\begin{array}{c}-0.267 * * * \\
(-9.056)\end{array}$ & $\begin{array}{c}-0.209 * * * \\
(-8.103)\end{array}$ & $\begin{array}{c}-0.300 * * * \\
(-11.295)\end{array}$ & $\begin{array}{c}-0.175^{* * *} \\
(-7.289)\end{array}$ & $\begin{array}{c}-0.291 * * * \\
(-7.131)\end{array}$ & $\begin{array}{c}-0.208 * * * \\
(-9.489)\end{array}$ \\
\hline Constant & $\begin{array}{c}6.520^{* * *} \\
(7.189)\end{array}$ & $\begin{array}{c}4.303^{* * *} \\
(8.203)\end{array}$ & $\begin{array}{c}3.104 * * * \\
(5.960)\end{array}$ & $\begin{array}{c}7.014 * * * \\
(6.037)\end{array}$ & $\begin{array}{c}6.996 * * * \\
(6.035)\end{array}$ & $\begin{array}{c}3.753^{* * * *} \\
(6.266)\end{array}$ & $\begin{array}{c}7.372^{* * * *} \\
(8.462)\end{array}$ & $\begin{array}{c}2.968 * * * \\
(5.256)\end{array}$ & $\begin{array}{c}8.825 * * * \\
(7.154)\end{array}$ & $\begin{array}{c}3.552 * * * \\
(6.684)\end{array}$ \\
\hline \# of observations & 643 & 1,878 & 1,534 & 987 & 581 & 1,940 & 860 & 1,661 & 345 & 2,176 \\
\hline Adjusted R-squared & 0.671 & 0.406 & 0.478 & 0.583 & 0.674 & 0.457 & 0.664 & 0.374 & 0.713 & 0.465 \\
\hline
\end{tabular}


